\title{
Digital Geologic Map of Arizona: A Digital Database Derived from the 1983 Printing of the Wilson, Moore, and Cooper 1:500,000-scale Map
}

By Douglas M. Hirschberg ${ }^{1}$ and G. Stephen Pitts ${ }^{1}$

Open-File Report 00-409

Version 1.0

Prepared in cooperation with the University of Arizona

2000

This report is preliminary and has not been reviewed for conformity with U.S. Geological Survey editorial standards or with the North American Stratigraphic Code. Any use of trade, product, or firm names is for descriptive purposes only and does not imply endorsement by the U.S. Government. The digital database is not meant to be used or displayed at any scale larger than 1:500,000 (e.g., 1:250,000 or 1:100,000).

Manuscript approved on October 10, 2000

U.S. DEPARTMENT OF THE INTERIOR

U.S. GEOLOGICAL SURVEY

${ }^{1}$ University of Arizona, Tucson, Arizona 85719 


\section{Table of Contents}

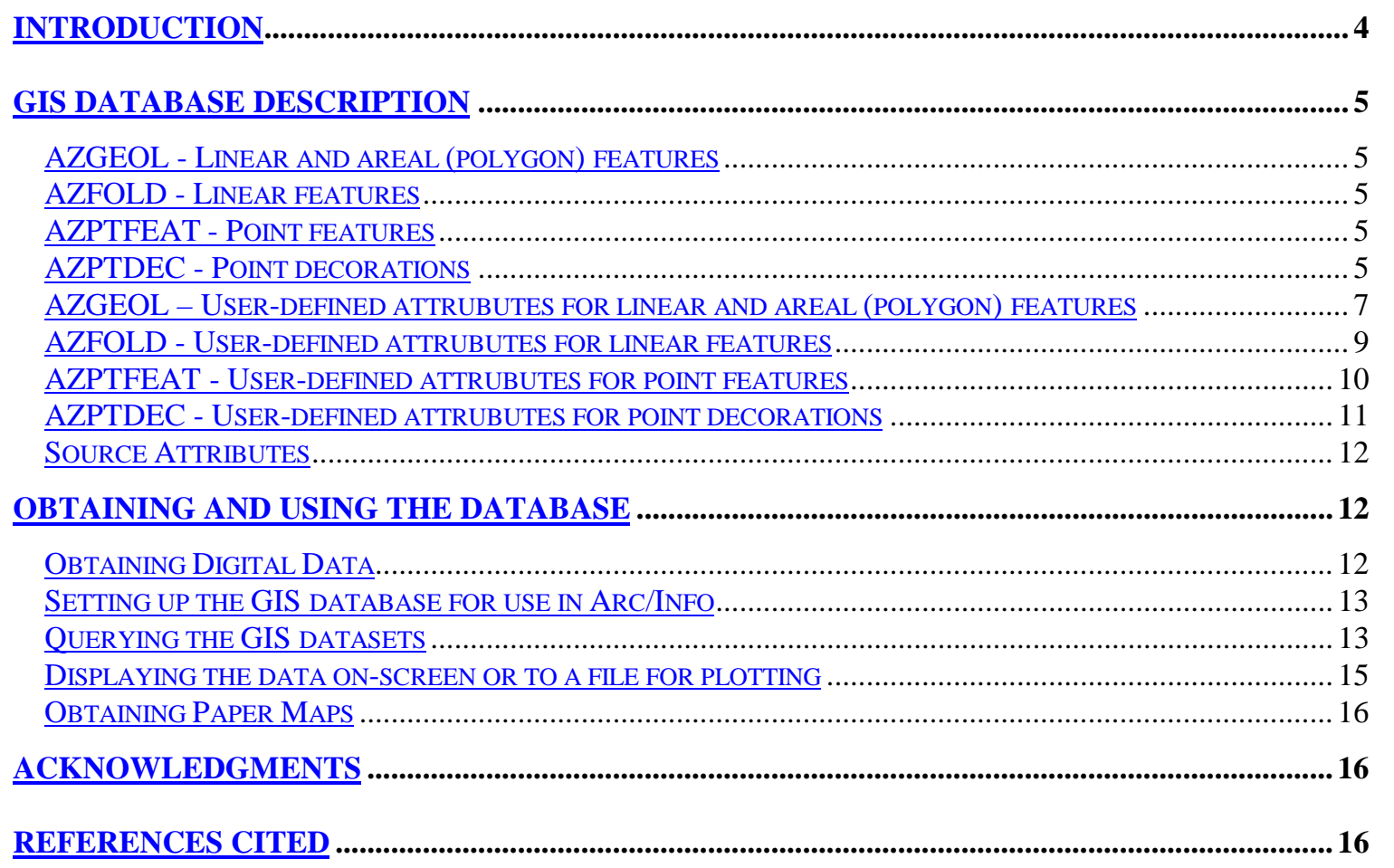

APPENDIX A: LIST OF FILES INCLUDED IN THIS OPEN-FILE REPORT ................................... 17

APPENDIX B: TRANSFORMATION REPORT ........................................................................................ 19

APPENDIX C: DESCRIBE OUTPUT FOR THE ARIZONA DATASETS .......................................21

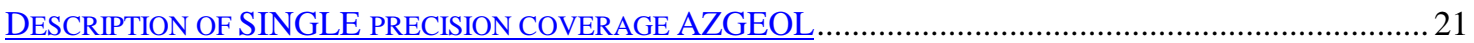

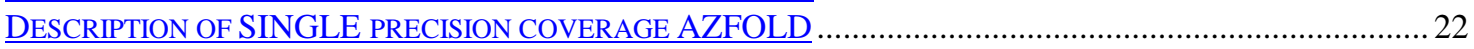

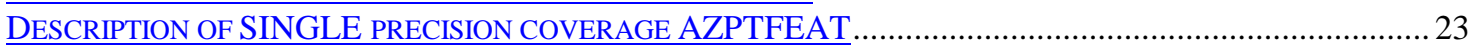

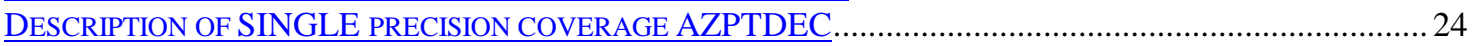

APPENDIX D: EXPLANATION OF GEOLOGIC MAP UNITS (FROM WILSON AND OTHERS,

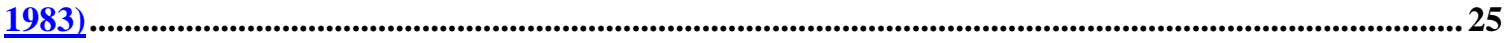

APPENDIX E: SOURCES FOR THE GEOLOGIC MAP OF ARIZONA (FROM WILSON AND OTHERS, 1983) ............................................................................................................................................ 30

APPENDIX F: METADATA (AZ500K.MET)

APPENDIX G: ARC/INFO MACRO LANGUAGE PROGRAM USED TO IMPORT THE

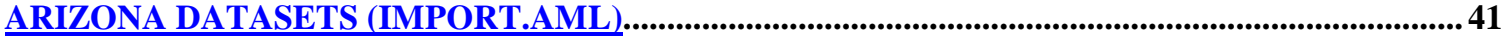

APPENDIX H: ARC/INFO MACRO LANGUAGE PROGRAMS USED TO CREATE GRAPHICS FILES FOR VIEWING AND PRINTING MAPS OF THE ARIZONA DATASETS (SHEET1.AML, SHEET2.AML, SHEET3.AML) ......................................................................................................................42

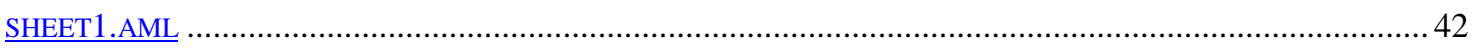

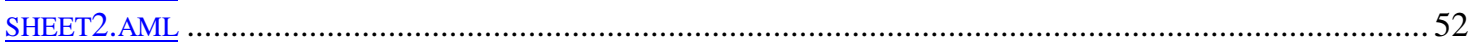

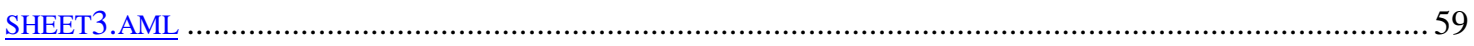




\section{LIST OF FIGURES AND TABLES}

Figure 1: Arc attribute table and related look-up tables for the AZGEOL dataset .................................... 6

Figure 2: Polygon attribute table and related look-up tables for the AZGEOL dataset .............................. 6

Figure 3: Point attribute table and related look-up tables for the AZPTFEAT dataset: .............................. 6

Figure 4: Arc attribute table and related look-up tables for the AZFOLD dataset:.................................... 6

Figure 5: Point attribute table and related look-up tables for the AZPTDEC dataset:................................ 6

Table 1: Description of items in the arc attribute table, AZGEOL.AAT, defining contacts, faults, and

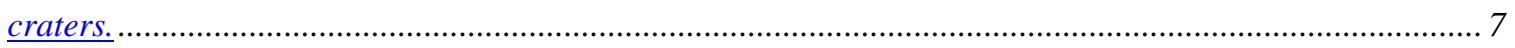

Table 2: Description of items in the contact (and boundary) look-up table AZGEOL.CON .......................... 7

Table 3: Description of items in the structure look-up table AZGEOL.STR …………................................ 8

Table 4: Description of items identifying geologic units in the polygon attribute table AZGEOL.PAT........ 8

Table 5: Description of items in the lithology (geologic map unit) look-up table AZGEOL.RU................... 9

Table 6: Description of items in the arc attribute table, AZFOLD.AAT, identifying interpreted linear

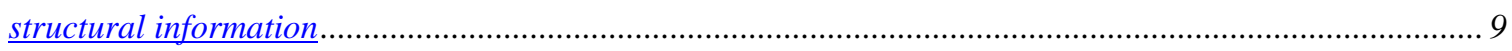

Table 7: Description of items in the structure look-up table AZFOLD.STR ………................................... 10

Table 8: Description of items identifying geologic points in the point attribute table AZPTFEAT.PAT.... 10

Table 9: Description of items in the geologic points look-up table AZPTFEAT.LUT .............................. 11

Table 10: Description of items identifying geologic points in the point attribute table, AZPTDEC.PAT ... 11

Table 11: Description of items in the geologic points look-up table AZPTDEC.LUT ............................. 11

Table 12: Description of items in AZFOLD.REF, AZGEOL.REF, AZPTDEC.REF, AZPTFEAT.REF,

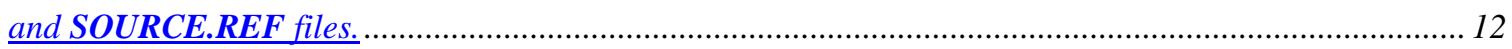

Table 13: RELATE1, relates between feature attribute tables and attributes.............................13

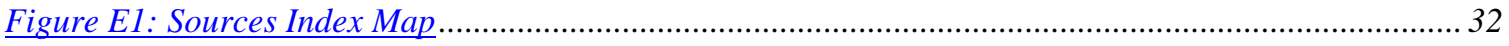




\section{Introduction}

This report describes a digital geologic GIS database in an Arc/Info format for the "Geologic Map of Arizona" by Wilson and others (1983 edition).

\section{Digital Processing}

The production acetates for the geologic map units, linework and points, and the hydrologic linework for the 1983 printing of the map were located in the USGS map archives in Reston VA. These were forwarded to Robert Miller, USGS Menlo Park, CA who affixed fiducial control points to the acetate layers. The acetates were then sent to Optronics Specialty Co., Northridge, CA to be scanned and vectorized. Four Arc/Info datasets were created and minimally attributed for fold axes, contacts and faults as lines; map units as polygons; and the symbols for fold axes and faults, and for cinder cones and diatremes as points. These datasets were delivered under contract to the U.S. Geological Survey.

Each of these four Arc/Info datasets was transformed from rectangular map inches into Lambert Conformal Conic map projection. The transformation with respect to a set of twenty-eight fiducial points (tics) resulted in a Root Mean Square (RMS) error of .004 (see Appendix B).

The datasets were extensively checked against the original source map (Wilson and others, 1969 and 1983 editions, 1983 acetate) for linework and attributional accuracy. Revisions were made to the linework and attributes as needed. Very small polygons that could not be positively identified were deleted, and other polygons that had been missed in the initial vectorization process were added.

Faults were attributed as displacement unknown if no displacement was indicated on the original map. Faults with U/D labels were attributed as normal faults with indicated throw. Faults with T labels were attributed as thrust faults, however, there was no consistent sense of upper plate or lower plate association for these faults; therefore, no attempt was made to indicate sense of motion in the digital files. One fault in the 1983 edition was labeled with offsetting arrows to indicate right-lateral offset, and it is so labeled in this database.

The overall accuracy (with respect to the location of lines and points) of the digital geologic map is probably no better than +/- 500 meters. This digital database is not meant to be used or displayed at any scale larger than 1:500,000 (e.g., 1:250,000 or 1:100,000). 


\section{GIS Database Description}

The Arizona GIS database consists of four Arc/Info datasets: AZGEOL (geology), AZFOLD (folds), AZPTFEAT (point features), and AZPTDEC (point decorations). The relationships between these datasets and their respective look-up (related) tables are illustrated in Figures 1, 2, 3, 4, and 5. Appendix C contains the output from the Arc/Info 'describe' command for each of the four datasets. Appendix D contains the listing of the explanation of the geologic map units found in the AZGEOL dataset. Appendix E contains the list of sources used by Wilson and others (1983) to compile the Geologic Map of Arizona. Appendix F contains the metadata for the digital geologic map database. Appendix A has the list of files in the Open-File Report.

\section{AZGEOL - Linear and areal (polygon) features}

The AZGEOL dataset contains the arcs representing contacts, faults, and maar craters (designated as calderas in the original manuscript), and the polygons representing the geologic map units. The explanation of geologic map units is given in Appendix D. Table 1 describes the user-defined attributes for items in the arc attribute table (azgeol.aat). Table 2 describes the attributes for items in the contact look-up table (azgeol.con). Table 3 describes the attributes for items in the structure look-up table (azgeol.str). Table 4 describes the user-defined attributes for items in the polygon attribute table (azgeol.pat). Table 5 describes the attributes for items in the geologic map unit look-up table (azgeol.ru).

\section{AZFOLD - Linear features}

The AZFOLD dataset contains those lines that represent fold axes (and their orientation as annotation). Table 6 describes the user-defined attributes for items in the arc attribute table (azfold.aat). Table 7 describes the attributes for items in the structure look-up table (azfold.str).

\section{AZPTFEAT - Point features}

The AZPTFEAT dataset contains points, which represent geologic features, cinder cones and diatremes. These points do not have strike or dip attribution. Table 8 describes the user-defined attributes for items in the point attribute table (azptfeat.pat). Table 9 describes the attributes for items in the geologic points look-up table (azptfeat.lut).

\section{AZPTDEC - Point decorations}

The AZPTDEC dataset consists of points used to symbolize the strike of bedding, foliation, or cleavage, fold axis type, and fold-axis plunge in the AZFOLD dataset or the fault offset in the AZGEOL dataset. Table 10 describes the items and attributes for the point attribute table (azptdec.pat). Table 11 describes the attributes for the geologic points look-up table (azptdec.lut) for the AZPTDEC Arc/Info file. 


\begin{tabular}{|l|}
\hline $\begin{array}{l}\text { Figure 1: Arc attribute } \\
\text { table and related look-up } \\
\text { tables for the AZGEOL } \\
\text { dataset }\end{array}$ \\
\hline azgeol.aat \\
\hline linecode \\
\hline source \\
\hline azgeol.con \\
\hline linecode \\
\hline symbol \\
\hline type \\
\hline modifier \\
\hline certainty \\
\hline desc \\
\hline azgeol.str \\
\hline linecode \\
\hline symbol \\
\hline type \\
\hline horizontal \\
\hline vertical \\
\hline fold \\
\hline plunge \\
\hline accuracy \\
\hline certainty \\
\hline desc \\
\hline azgeol.ref \\
\hline source \\
\hline scale \\
\hline authors \\
\hline year \\
\hline reference: \\
\hline
\end{tabular}
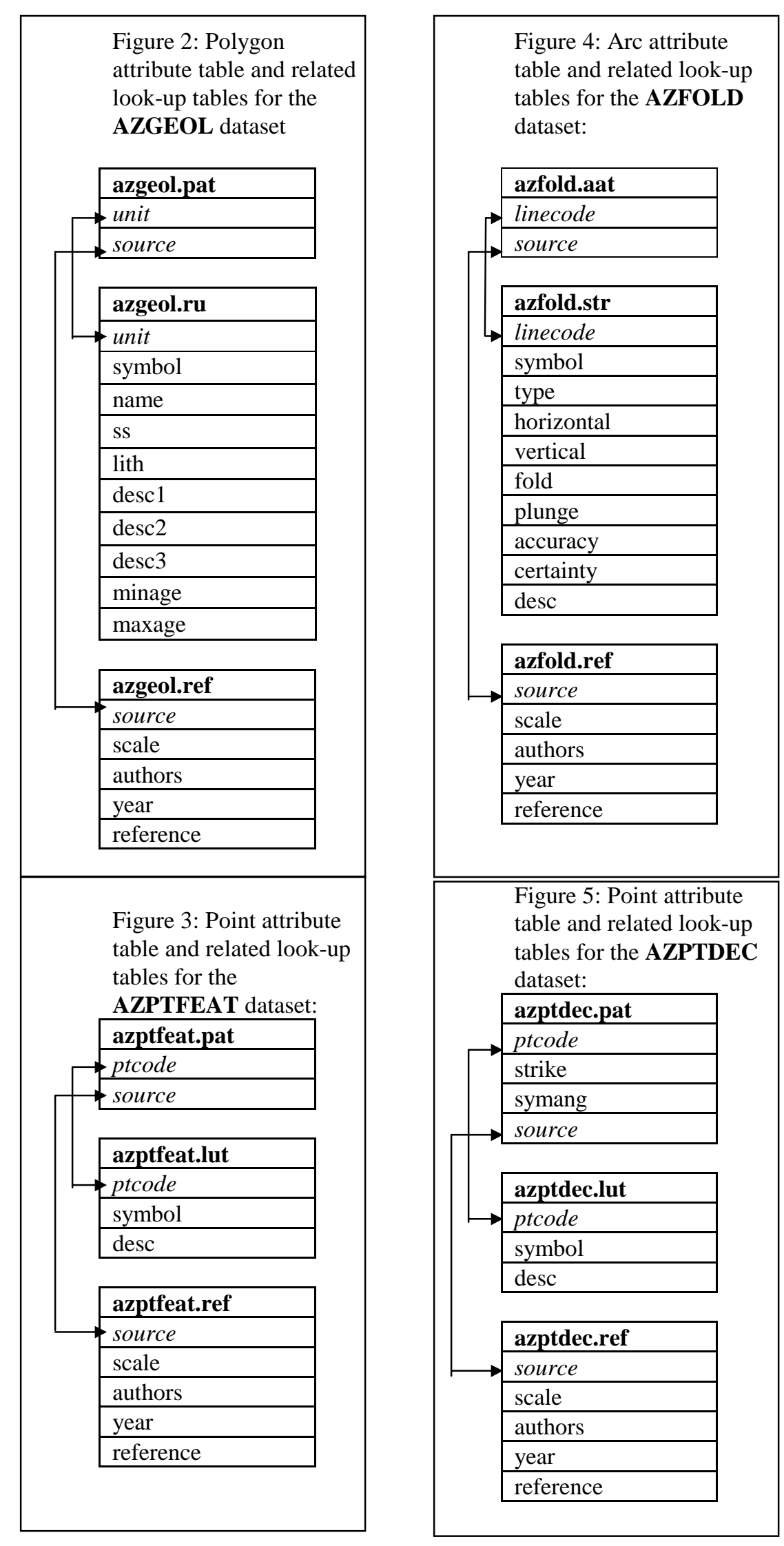


\section{AZGEOL - User-defined attributes for linear and areal (polygon) features}

Table 1: Description of items in the arc attribute table, AZGEOL.AAT, defining contacts, faults, and craters.

\begin{tabular}{|l|l|l|l|}
\hline AZGEOL.AAT \\
\hline $\begin{array}{l}\text { ITEM } \\
\text { NAME }\end{array}$ & ITEM TYPE & $\begin{array}{l}\text { ITEM } \\
\text { LENGTH }\end{array}$ & ATTRIBUTE DESCRIPTION \\
\hline linecode & integer & 3 & $\begin{array}{l}\text { Numeric code used to identify type of linear feature. } \\
\text { Linecodes < 100 are used for contacts and boundaries which are } \\
\text { described in the AZGEOL.CON file. } \\
\text { Linecodes > 100 and < 600 represent structural features which are } \\
\text { described in the AZGEOL.STR file. }\end{array}$ \\
\hline source & integer & 4 & $\begin{array}{l}\text { Numeric code used to identify the data source for the linear feature. } \\
\text { Complete references for the sources are listed in the AZGEOL.REF } \\
\text { file. }\end{array}$ \\
\hline
\end{tabular}

Table 2: Description of items in the contact (and boundary) look-up table AZGEOL.CON

\begin{tabular}{|l|l|l|l|}
\hline \multicolumn{2}{|l|}{ AZGEOL.CON } \\
\hline $\begin{array}{l}\text { ITEM } \\
\text { NAME }\end{array}$ & ITEM TYPE & $\begin{array}{l}\text { ITEM } \\
\text { LENGTH }\end{array}$ & ATTRIBUTE DESCRIPTION \\
\hline linecode & integer & 3 & $\begin{array}{l}\text { Numeric code (a value < 100) used to identify type of contact or } \\
\text { boundary. (This item also occurs in AZGEOL.AAT.) }\end{array}$ \\
\hline symbol & integer & 3 & $\begin{array}{l}\text { Line symbol number used by Arc/Info to plot arcs. } \\
\text { Symbol numbers refer to the SCAMP2B.LIN lineset (after Matti } \\
\text { and others, 1997) }\end{array}$ \\
\hline type & character & 10 & Major type of line, e.g., contact, map boundary. \\
\hline modifier & character & 20 & $\begin{array}{l}\text { Line type modifier, i.e., approximate, concealed, gradational. No } \\
\text { entry implies 'known.' }\end{array}$ \\
\hline certainty & character & 15 & $\begin{array}{l}\text { Degree of certainty of contact or boundary, i.e., inferred, uncertain. } \\
\text { No entry implies 'certain.' }\end{array}$ \\
\hline desc & character & 100 & Written description or explanation of contact or boundary. \\
\hline
\end{tabular}


Table 3: Description of items in the structure look-up table AZGEOL.STR

\begin{tabular}{|l|l|l|l|}
\hline AZGEOL.STR & ITEM TYPE & $\begin{array}{l}\text { ITEM } \\
\text { LENGTH }\end{array}$ & ATTRIBUTE DESCRIPTION \\
\hline NAME & integer & 3 & $\begin{array}{l}\text { Numeric code (a value > 100 and < 600) used to identify type of } \\
\text { structural feature. (This item also occurs in AZGEOL.AAT.) }\end{array}$ \\
\hline symbol & integer & 3 & $\begin{array}{l}\text { Line symbol number used by Arc/Info to plot arcs. } \\
\text { Symbol numbers refer to the SCAMP2B.LIN lineset (after Matti } \\
\text { and others, 1997). }\end{array}$ \\
\hline type & character & 10 & Major type of structure, i.e., fault, fracture, other. \\
\hline horizontal & character & 20 & $\begin{array}{l}\text { Type of horizontal fault movement, e.g., left-lateral, right-lateral. No } \\
\text { entry implies 'unknown.' }\end{array}$ \\
\hline vertical & character & 20 & $\begin{array}{l}\text { Type of vertical fault movement, e.g., normal. No entry implies } \\
\text { 'unknown.' }\end{array}$ \\
\hline fold & character & 15 & Type of fold, not used in this table. \\
\hline plunge & character & 15 & Type of plunge on fold, not used in this table. \\
\hline accuracy & character & 15 & $\begin{array}{l}\text { Line type modifier indicating degree of accuracy, i.e., approximately } \\
\text { located, concealed, gradational. No entry implies 'known.' }\end{array}$ \\
\hline certainty & character & 15 & $\begin{array}{l}\text { Degree of certainty of structure, i.e., inferred, uncertain. No entry } \\
\text { implies 'certain.' }\end{array}$ \\
\hline desc & character & 100 & Written description or explanation of structural feature. \\
\hline
\end{tabular}

Table 4: Description of items identifying geologic units in the polygon attribute table AZGEOL.PAT

\begin{tabular}{|c|c|c|c|}
\hline \multicolumn{4}{|c|}{ AZGEOL.PAT } \\
\hline $\begin{array}{l}\text { ITEM } \\
\text { NAME }\end{array}$ & ITEM TYPE & $\begin{array}{l}\text { ITEM } \\
\text { LENGTH }\end{array}$ & ATTRIBUTE DESCRIPTION \\
\hline unit & character & 10 & $\begin{array}{l}\text { Alphabetic character string used to identify the geologic map unit, } \\
\text { which is described in the AZGEOL.RU look-up table. (This item } \\
\text { also occurs in AZGEOL.RU.) }\end{array}$ \\
\hline source & integer & 4 & $\begin{array}{l}\text { Numeric code used to identify the data source for the geologic map } \\
\text { unit. Complete references for the sources are listed in the } \\
\text { AZGEOL.REF file. }\end{array}$ \\
\hline
\end{tabular}


Table 5: Description of items in the lithology (geologic map unit) look-up table AZGEOL.RU (for use with the AZ500K.SHD shadeset).

\begin{tabular}{|c|c|c|c|}
\hline \multicolumn{4}{|c|}{ AZGEOL.RU } \\
\hline $\begin{array}{l}\text { ITEM } \\
\text { NAME }\end{array}$ & ITEM TYPE & $\begin{array}{l}\text { ITEM } \\
\text { LENGTH }\end{array}$ & ATTRIBUTE DESCRIPTION \\
\hline unit & character & 10 & $\begin{array}{l}\text { Alphabetic character label used to identify the geologic map unit. } \\
\text { (This item also occurs in AZGEOL.PAT.) }\end{array}$ \\
\hline symbol & integer & 3 & $\begin{array}{l}\text { Shadeset symbol number used by Arc/Info to plot a filled/shaded } \\
\text { polygon. The symbol numbers used in this file refer to the } \\
\text { AZ500K.SHD shadeset. }\end{array}$ \\
\hline name & character & 50 & $\begin{array}{l}\text { The prefix portion of the geologic map unit label that does not } \\
\text { include subscripts. (If subscripting is not used in the original } \\
\text { geologic map unit label, then the 'name' entry is the same as the } \\
\text { 'unit' entry.) }\end{array}$ \\
\hline SS & character & 4 & The suffix portion of the geologic unit label that includes subscripts. \\
\hline lith & character & 25 & $\begin{array}{l}\text { Major type of lithogenesis of the geologic map unit, i.e., } \\
\text { unconsolidated sediments, sedimentary rocks, metasedimentary } \\
\text { rocks, intrusive rocks, extrusive rocks, or metamorphic rocks, OR } \\
\text { water or ice. }\end{array}$ \\
\hline desc1 & character & 200 & Geologic map unit explanation. \\
\hline $\operatorname{desc} 2$ & character & 200 & Continuation of geologic map unit explanation if necessary. \\
\hline desc3 & character & 200 & Continuation of geologic map unit explanation if necessary. \\
\hline minage & character & 7 & $\begin{array}{l}\text { Minimum stratigraphic age of geologic map unit, i.e., CRET, TERT, } \\
\text { PCY. }\end{array}$ \\
\hline maxage & character & 7 & Maximum stratigraphic age of geologic map unit \\
\hline
\end{tabular}

\section{AZFOLD - User-defined attributes for linear features}

Table 6: Description of items in the arc attribute table, AZFOLD.AAT, identifying interpreted linear structural information

\begin{tabular}{|l|l|l|l|}
\hline \multicolumn{2}{|l|}{ AZFOLD.AAT } \\
\hline $\begin{array}{l}\text { ITEM } \\
\text { NAME }\end{array}$ & ITEM TYPE & $\begin{array}{l}\text { ITEM } \\
\text { LENGTH }\end{array}$ & ATTRIBUTE DESCRIPTION \\
\hline linecode & integer & 3 & $\begin{array}{l}\text { Linecodes }>100 \text { and < 600 represent structural features which are } \\
\text { described in the AZFOLD.STR file. }\end{array}$ \\
\hline source & integer & 4 & $\begin{array}{l}\text { Numeric code used to identify the data source for the linear feature. } \\
\text { Complete references for the sources are listed in the AZFOLD.REF } \\
\text { file. }\end{array}$ \\
\hline
\end{tabular}


Table 7: Description of items in the structure look-up table AZFOLD.STR

\begin{tabular}{|l|l|l|l|}
\hline AZFOLD.STR & ITEM TYPE & $\begin{array}{l}\text { ITEM } \\
\text { LENGTH }\end{array}$ & ATTRIBUTE DESCRIPTION \\
\hline NAME & ITEM & 3 & $\begin{array}{l}\text { Numeric code (a value > 100 and < 600) used to identify type of } \\
\text { structural feature. (This item also occurs in AZFOLD.AAT.) }\end{array}$ \\
\hline linecode & Integer & 3 & $\begin{array}{l}\text { Line symbol number used by Arc/Info to plot arcs. } \\
\text { Symbol numbers refer to the SCAMP2B.LIN lineset (after Matti } \\
\text { and others, 1997). }\end{array}$ \\
\hline type & Character & 10 & Major type of fault, not used in this table \\
\hline horizontal & Character & 20 & Type of horizontal fault movement, not used in this table. \\
\hline vertical & Character & 20 & Type of vertical fault movement, not used in this table. \\
\hline fold & Character & 15 & Type of fold, e.g., anticline, syncline. \\
\hline plunge & character & 15 & $\begin{array}{l}\text { Type of plunge on fold, i.e., horizontal, plunging, plunging in, } \\
\text { plunging out. }\end{array}$ \\
\hline accuracy & Character & 15 & $\begin{array}{l}\text { Line type modifier indicating degree of accuracy, i.e., approximately } \\
\text { located, concealed, gradational.. No entry implies 'known.' }\end{array}$ \\
\hline certainty & Character & 15 & $\begin{array}{l}\text { Degree of certainty of structural feature, i.e., inferred, uncertain. No } \\
\text { entry implies 'certain.' }\end{array}$ \\
\hline desc & Character & 100 & Written description or explanation of structural feature. \\
\hline
\end{tabular}

\section{AZPTFEAT - User-defined attributes for point features}

Table 8: Description of items identifying geologic points in the point attribute table AZPTFEAT.PAT

\begin{tabular}{|l|l|l|l|}
\hline \multicolumn{2}{|l|}{ AZPTFEAT.PAT } \\
\hline $\begin{array}{l}\text { ITEM } \\
\text { NAME }\end{array}$ & ITEM TYPE & $\begin{array}{l}\text { ITEM } \\
\text { LENGTH }\end{array}$ & ATTRIBUTE DESCRIPTION \\
\hline ptcode & integer & 3 & $\begin{array}{l}\text { Type of point symbol, Cinder cone or Diatreme. (This item also } \\
\text { occurs in the AZPTFEAT.LUT file.) }\end{array}$ \\
\hline source & integer & 4 & $\begin{array}{l}\text { Numeric code used to identify the data source for the structural map } \\
\text { symbol. Complete references for the sources are listed in the } \\
\text { AZPTFEAT.REF file. }\end{array}$ \\
\hline
\end{tabular}


Table 9: Description of items in the geologic points look-up table AZPTFEAT.LUT

\begin{tabular}{|l|l|l|l|}
\hline AZPTFEAT.LUT \\
\hline $\begin{array}{l}\text { ITEM } \\
\text { NAME }\end{array}$ & ITEM TYPE & $\begin{array}{l}\text { ITEM } \\
\text { LENGTH }\end{array}$ & ATTRIBUTE DESCRIPTION \\
\hline ptcode & integer & 3 & $\begin{array}{l}\text { Type of point symbol, Cinder cone or Diatreme. (This item also } \\
\text { occurs in the AZPTFEAT.PAT file.) }\end{array}$ \\
\hline symbol & integer & 3 & $\begin{array}{l}\text { Marker symbol number used by Arc/Info to identify type of geologic } \\
\text { map symbol. Symbol numbers refer to the SCAMP2B.MRK } \\
\text { markerset (Matti and others, 1997). }\end{array}$ \\
\hline desc & character & 70 & Written description or explanation of map symbol. \\
\hline
\end{tabular}

\section{AZPTDEC - User-defined attributes for point decorations}

Table 10: Description of items identifying geologic points in the point attribute table, AZPTDEC.PAT

\begin{tabular}{|l|l|l|l|}
\hline AZPTDEC.PAT & $\begin{array}{l}\text { ITEM } \\
\text { LENGTH }\end{array}$ & ATTRIBUTE DESCRIPTION \\
\hline ITEM NAME & integer & 3 & $\begin{array}{l}\text { Type of point symbol, e.g., fold type, fold plunge or fault offset } \\
\text { (This item also occurs in the AZPTDEC.LUT file.) }\end{array}$ \\
\hline ptcode & integer & 3 & $\begin{array}{l}\text { Strike of bedding, foliation or cleavage. } \\
\text { Not applicable in this database. }\end{array}$ \\
\hline symang & integer & 4 & $\begin{array}{l}\text { The angle used to complete the mathematical rotation of the } \\
\text { structural map symbol to its proper orientation on the map. } \\
\text { This value is the \$angle pseudo-item value for the point. }\end{array}$ \\
\hline source & integer & 4 & $\begin{array}{l}\text { Numeric code used to identify the data source for this map } \\
\text { symbol. Complete references for the sources are listed in the } \\
\text { AZPTDEC.REF file. }\end{array}$ \\
\hline
\end{tabular}

Table 11: Description of items in the geologic points look-up table AZPTDEC.LUT

\begin{tabular}{|l|l|l|l|}
\hline AZPTDEC.LUT \\
\hline $\begin{array}{l}\text { ITEM } \\
\text { NAME }\end{array}$ & ITEM TYPE & $\begin{array}{l}\text { ITEM } \\
\text { LENGTH }\end{array}$ & ATTRIBUTE DESCRIPTION \\
\hline ptcode & integer & 3 & $\begin{array}{l}\text { Type of point symbol, e.g., fold type, fold plunge or fault offset (This } \\
\text { item also occurs in the AZPTDEC.PAT file.) }\end{array}$ \\
\hline symbol & integer & 3 & $\begin{array}{l}\text { Marker symbol number used by Arc/Info to identify type of geologic } \\
\text { map symbol. Symbol numbers refer to the SCAMP2B.MRK } \\
\text { markerset (Matti and others, 1997). }\end{array}$ \\
\hline desc & character & 70 & Written description or explanation of map symbol. \\
\hline
\end{tabular}




\section{Source Attributes}

Table 12: Description of items in AZFOLD.REF, AZGEOL.REF, AZPTDEC.REF, AZPTFEAT.REF, and SOURCE.REF files.

\begin{tabular}{|l|l|l|l|}
\hline \multicolumn{3}{|l|}{ AZFOLD.REF / AZGEOL.REF / AZPTDEC.REF / AZPTFEAT.REF / SOURCE.REF } \\
\hline $\begin{array}{l}\text { ITEM } \\
\text { NAME }\end{array}$ & ITEM TYPE & $\begin{array}{l}\text { ITEM } \\
\text { LENGTH }\end{array}$ & ATTRIBUTE DESCRIPTION \\
\hline source & integer & 4 & $\begin{array}{l}\text { Numeric code used to identify the data source. (This item also } \\
\text { occurs in the AZFOLD.AAT, AZGEOL.AAT AZGEOL.PAT, } \\
\text { AZPTDEC.PAT, and AZPTFEAT.PAT files.) }\end{array}$ \\
\hline scale & integer & 10 & $\begin{array}{l}\text { Scale of source map. (This value is the denominator of the } \\
\text { proportional fraction that identifies the scale of the map that was } \\
\text { digitized or scanned to produce the digital map.) }\end{array}$ \\
\hline authors & character & 200 & $\begin{array}{l}\text { Author(s) or compiler(s) of source map entered as last name, first } \\
\text { name or initial, and middle initial. }\end{array}$ \\
\hline year & integer & 4 & Source (map) publication date \\
\hline reference & character & 250 & Remainder of reference in USGS reference format. \\
\hline
\end{tabular}

\section{Obtaining and Using the Database}

\section{Obtaining Digital Data}

The complete database for the digital geologic map of Arizona is available in Arc/Info interchange format with associated data files. These data and map images are maintained in a Lambert Conformal Conic projection with the following parameters:
1st standard parallel
$\begin{array}{lll}33 & 0 & 0.00\end{array}$
2nd standard parallel
$\begin{array}{lll}45 & 0 & 0.00\end{array}$
central meridian
$\begin{array}{lll}-112 & 0 & 0.00\end{array}$
latitude of projection's origin
$\begin{array}{lll}0 & 0 & 0.00\end{array}$
false easting (meters)
0.00
false northing (meters)
0.00

To obtain copies of the digital data, do one of the following:

Download the digital files from the USGS public access

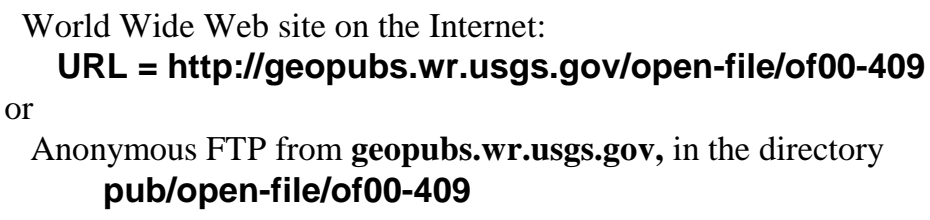

World Wide Web site on the Internet:

URL = http://geopubs.wr.usgs.gov/open-file/of00-409

or

Anonymous FTP from geopubs.wr.usgs.gov, in the directory pub/open-file/of00-409

The Internet sites contain the complete database for the digital geologic map of Arizona. To manipulate these data in a geographic information system (GIS), you must have a GIS that is capable of reading Arc/Info interchange-format files. 


\section{Setting up the GIS database for use in Arc/Info}

Create an Arc/Info workspace, move to it, and download all the files from the OFR into that space. Start Arc/Info and run the import.aml program (i.e., Arc: \&run import, see Appendix G) to import the Arc/Info interchange format files (*.e00). This procedure must be performed prior to using data in Arc/Info. To open the *.e00 files for use in ArcView, one needs to run "Import71" for each file.

\section{Querying the GIS datasets}

To access information contained in the associated tables a "relate" must be established between the coverages (datasets) and the associated INFO tables. A file, relate1, has been provided with the digital data to establish relates (relations) between coverage feature attribute tables and associated INFO tables. You can use the relates in Arc/Info to link each feature with associated data.

Seven relates (relations) are defined in relate1. Table 13 shows the relations between the various feature attribute table items and INFO database tables.

Table 13: RELATE1, relates between feature attribute tables and attributes.

\begin{tabular}{|c|c|c|c|c|c|c|}
\hline \multicolumn{7}{|l|}{ RELATE1 } \\
\hline RELATION & TABLE-ID & DATABASE & ITEM & COLUMN & TYPE & ACCESS \\
\hline$\overline{\text { FOLDSTR }}$ & azfold.str & info & LINECODE & linecode & ORDERED & RW \\
\hline GEOLCON & azgeol.con & info & LINECODE & linecode & ORDERED & RW \\
\hline GEOLSTR & azgeol.str & info & LINECODE & linecode & ORDERED & RW \\
\hline GEOLRU & azgeol.ru & info & UNIT & unit & ORDERED & RW \\
\hline PTDEC & azptdec.lut & info & PTCODE & ptcode & ORDERED & RW \\
\hline PTFEAT & azptfeat.lut & info & PTCODE & ptcode & ORDERED & RW \\
\hline SOURCES & sources.ref & info & SOURCE & source & ORDERED & RW \\
\hline
\end{tabular}

To establish (restore) these relates (relations), see the 'relate' command usage in the respective Arc/Info module.

Once you have restored the relates (relations) you can query an INFO table respective to the particular coverage and feature.

*When querying arcs representing contacts, map boundaries, water boundaries, etc. (linecodes 1 to 99) in the azgeol dataset, use the relation "geolcon" to access information in the look-up table, azgeol.con.

*When querying faults and other structural arcs ( linecodes greater than or equal to 100) in the azgeol dataset, use the relation "geolstr" to access information in the look-up table azgeol.str. 
*When querying polygons in the azgeol dataset, use the relation "geolru" to access information in the look-up table azgeol.ru.

*When querying arcs in the azfold dataset, use the relation "foldstr" to access information in the look-up table azfold.str.

*When querying points in the azptfeat dataset, use the relation "ptfeat" to access information in the look-up table azptfeat.lut.

*When querying points in the azptdec dataset, use the relation "ptdec" to access information in the look-up table azptdec.lut.

\section{An example of querying the AZGEOL dataset and related tables in ArcEdit:}

(Text in serif 'Courier New' font represents the prompt and output from ArcEdit, text in sans-serif 'Arial' represents what was typed in at the prompt and additional comments, other words are in bold for emphasis)

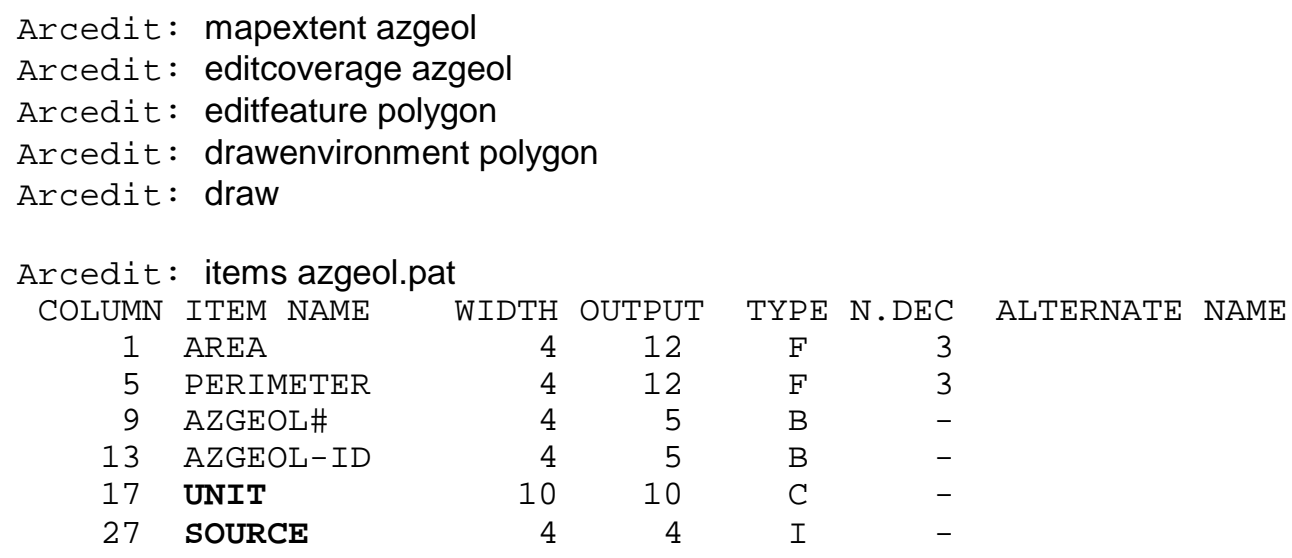

(UNIT is the key field in the relate between azgeol.pat and azgeol.ru using the relation "geolru")

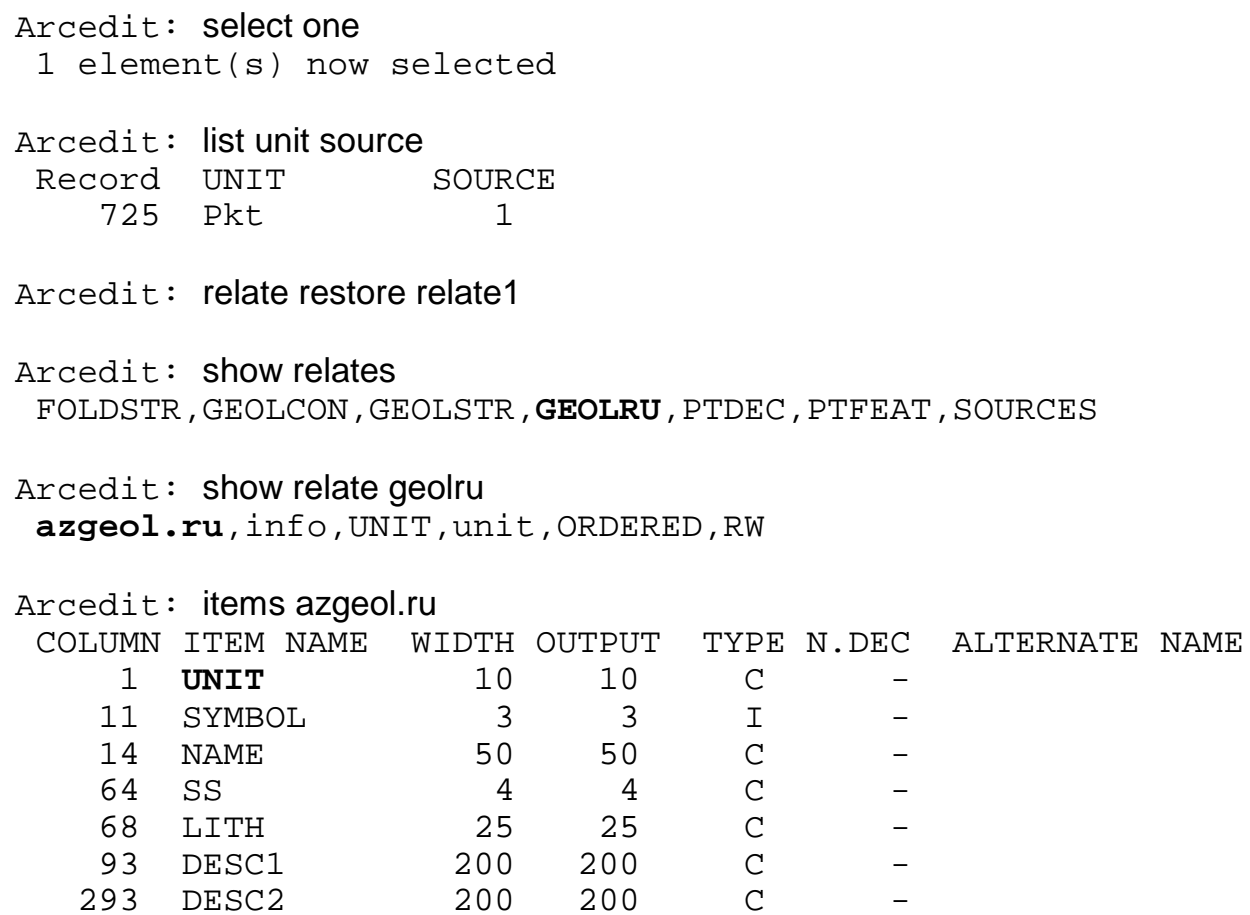




\section{Obtaining Paper Maps}

Paper copies of the digital geologic map are not available from the U.S. Geological Survey. However, with access to the Internet and access to a large-format color plotter that can interpret graphics metafiles or HP-RTL files, a 1:500,000-scale paper copy of a geologic-map can be made by downloading, processing, and plotting sheet1.gra, sheet2.gra , and sheet3.gra, or by downloading and plotting the three sheets: sheet1.rtl sheet2.rtl and sheet3.rtl, (described above). Sheet1.rtl can only be plotted on a 46" format plotter. Sheet2.rtl and sheet3.rtl can be plotted on a 36" format plotter.

\section{Acknowledgments}

We wish to thank Jonathan Matti, U.S. Geological Survey for his assistance in creating a structure for the digital GIS datasets; Richard Koch for helping to locate the acetate separates used to print the original paper map; and Robert J. Miller for locating and affixing fiducial control points to the acetates prior to the scanning process.

We wish to thank and acknowledge the efforts of our reviewers, Karen Bolm, Floyd Gray, and Pamela Derkey.

\section{References Cited}

Matti, J.C., Miller, F.K., Powell, R.E., Kennedy, S.A., Bunyapanasarn, T.P., Koukladas, C., Hauser, R.M., and Cossette, P.M., 1997, Geologic-point attributes for digital geologic-map data bases produced by the Southern California Areal Mapping Project (SCAMP): U.S. Geological Survey Open-File Report 97-859, 7 p.

URL: http://scamp.wr.usgs.gov/lineset.tar and http://scamp.wr.usgs.gov/markerset.tar

Wilson, E. D., Moore, R. T., and Cooper, J. R., 1969, Geologic Map of Arizona, 1 sheet, scale: 1:500,000. (1969 printing, USGS Map G61063; 1983 printing, USGS Map G810436) 


\section{Appendix A: List of files included in this Open-File Report}

Only the files created by the authors are listed; the files that accompany a dataset that are automatically created and maintained by Arc/Info are not listed.

The Arc/Info interchange files (*.e00) were created using the default values for compression and max_lines (see the Arc/Info 'export' command). Indented entries are files created by running the Arc/Info 'import' command on the preceding Arc/Info interchange file. The Arc/Info macro named import.aml will do the import process automatically.

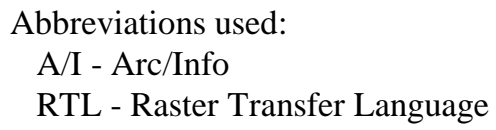

\begin{tabular}{|c|c|c|}
\hline NAME & FORMAT & BRIEF DESCRIPTION \\
\hline az500k.pdf & Adobe Acrobat PDF & Open-File Report text \\
\hline az500k.met & text & Metadata file for the database \\
\hline az500ks.e00 & Arc/Info interchange file & \\
\hline az500k.shd & Arc/Info shadeset & Polygon shades for geologic map units \\
\hline azfold.e00 & Arc/Info interchange file & \\
\hline azfold & Arc/Info coverage & Geologic fold axes arcs dataset \\
\hline azfold.str & INFO database table & Look-up table with structure attributes for azfold dataset \\
\hline azfold.ref & INFO database table & Look-up table with source attributes for azfold dataset \\
\hline azgeol.e00 & Arc/Info interchange file & \\
\hline azgeol & Arc/Info coverage & $\begin{array}{l}\text { Geologic contacts and fault arcs and geologic map unit polygons } \\
\text { dataset }\end{array}$ \\
\hline azgeol.con & INFO database table & Look-up table with contact attributes for azgeol dataset \\
\hline azgeol.str & INFO database table & Look-up table with structure attributes for azgeol dataset \\
\hline azgeol.ru & INFO database table & Look-up table with map unit attributes for azgeol dataset \\
\hline azgeol.ref & INFO database table & Look-up table with source attributes for azgeol dataset \\
\hline azptdec.e00 & Arc/Info interchange file & \\
\hline azptdec & Arc/Info coverage & Points to decorate fault and fold axes arcs dataset \\
\hline azptdec.lut & INFO database table & Look-up table with point attributes for azptdec dataset \\
\hline azptdec.ref & INFO database table & Look-up table with source attributes for azptdec dataset \\
\hline azptfeat.e00 & Arc/Info interchange file & \\
\hline azptfeat & Arc/Info coverage & Geologic features points dataset \\
\hline azptfeat.lut & INFO database table & Look-up table with point attributes for azptfeat dataset \\
\hline azptfeat.ref & INFO database table & Look-up table with source attributes for azptfeat dataset \\
\hline disclaim.tex & text & Disclaimer for map sheets \\
\hline fnt026.e00 & Arc/Info interchange file & \\
\hline fnt026 & Arc/Info font file & Font patterns used by scamp2b.lin \\
\hline $\begin{array}{l}\text { fnt037.e00 } \\
\text { fnt037 }\end{array}$ & $\begin{array}{l}\text { Arc/Info interchange file } \\
\text { Arc/Info font file }\end{array}$ & Font patterns used by scamp2b.mrk \\
\hline
\end{tabular}




\begin{tabular}{|c|c|c|}
\hline geo_dd.prj & text & Arc/Info projection file \\
\hline import.aml & text & Arc/Info macro to import interchange (*.e00) files \\
\hline indxbib1.tex & text & Sources bibliography for Wilson and others 1983 map, column 1 \\
\hline indxbib2.tex & text & Sources bibliography for Wilson and others 1983 map, column 2 \\
\hline lamb.prj & text & Arc/Info Lambert projection file \\
\hline lambinfo.tex & text & Lambert projection parameters for maps \\
\hline mapbar.aml & text & A/I macro to create a scale bar graphic \\
\hline mapcred.tex & text & Map and database credits \\
\hline ofrlin.key & text & Arc/Info line key \\
\hline ofrmrk.key & text & Arc/Info marker key \\
\hline ofrshd.key & text & Arc/Info shade key \\
\hline readme.txt & text & List of files in the Open-File Report \\
\hline $\begin{array}{l}\text { relate1.e00 } \\
\text { relate } 1\end{array}$ & $\begin{array}{l}\text { Arc/Info interchange file } \\
\text { INFO database table }\end{array}$ & Relates for datasets and associated tables \\
\hline refs.tex & text & Explanation references for Wilson and others 1983 map \\
\hline $\begin{array}{l}\text { scamp2bl.e00 } \\
\text { scamp2b.lin }\end{array}$ & $\begin{array}{l}\text { Arc/Info interchange file } \\
\text { Arc/Info lineset }\end{array}$ & Line symbols for arcs \\
\hline $\begin{array}{l}\text { scamp2bm.e00 } \\
\text { scamp2b.mrk }\end{array}$ & $\begin{array}{l}\text { Arc/Info interchange file } \\
\text { Arc/Info markerset }\end{array}$ & Marker symbols for points \\
\hline $\begin{array}{l}\text { sheet1.aml } \\
\text { sheet2.aml } \\
\text { sheet3.aml }\end{array}$ & $\begin{array}{l}\text { text } \\
\text { text } \\
\text { text }\end{array}$ & $\begin{array}{l}\text { Arc/Info macro to create sheet1.gra - complete state map } \\
\text { Arc/Info macro to create sheet } 2 . \text { gra - north part of state map } \\
\text { Arc/Info macro to create sheet3.gra - south part of state map }\end{array}$ \\
\hline $\begin{array}{l}\text { sheet1.gra } \\
\text { sheet2.gra } \\
\text { sheet3.gra }\end{array}$ & $\begin{array}{l}\text { A/I graphics file } \\
\text { A/I graphics file } \\
\text { A/I graphics file }\end{array}$ & $\begin{array}{l}46 " \text { x } 68 " \text { geology map composition } \\
46 " \text { x 35" geology map composition } \\
46 " \text { x 35" geology map composition }\end{array}$ \\
\hline $\begin{array}{l}\text { sheet1.rtl } \\
\text { sheet2.rtl / .pdf } \\
\text { sheet3.rtl / .pdf }\end{array}$ & $\begin{array}{l}\text { RTL } \\
\text { RTL / PDF } \\
\text { RTL / PDF }\end{array}$ & $\begin{array}{l}\text { 46" x 68" geology map composition - complete state map } \\
35 " \text { x 46" geology map (rotated } 90 \mathrm{deg} .) \text { - north part of state map } \\
35 " \text { x 46" geology map (rotated } 90 \mathrm{deg} .) \text { - south part of state map }\end{array}$ \\
\hline sheetidx.gra & A/I graphics file & Graphic for map sheet index \\
\hline $\begin{array}{l}\text { sources.e00 } \\
\text { sources.ref }\end{array}$ & $\begin{array}{l}\text { Arc/Info interchange file } \\
\text { INFO database table }\end{array}$ & Source attributes for features in all datasets \\
\hline srcmap.gra & A/I graphics file & Graphic showing map sources (from Wilson and others, 1983) \\
\hline usgslogo.gra & $\mathrm{A} / \mathrm{I}$ graphics file & Graphic for U.S. Geological Survey visual identifier \\
\hline
\end{tabular}




\section{Appendix B: Transformation report}

This listing is the result of the Arc/Info 'transform' command creating the dataset (coverage) azgeol, and is typical of the results from the transform used to create the four datasets (coverages) described in this report.

Scale $(\mathrm{X}, \mathrm{Y})=(12707.431,12696.837)$

Skew (degrees) $=(-0.023)$

Rotation (degrees) $=(-0.025)$

Translation $=(-266712.410,3687089.416)$

RMS Error (input,output) $=(0.004,54.930)$

Affine $X=A x+B y+C$

$\mathrm{Y}=\mathrm{Dx}+\mathrm{Ey}+\mathrm{F}$

$\mathrm{A}=12707.430 \mathrm{~B}=\quad 0.421 \mathrm{C}=-266712.410$

$\mathrm{D}=\quad-5.588 \mathrm{E}=12696.838 \mathrm{~F}=3687089.416$

tic id

input $\mathrm{x} \quad$ input $\mathrm{y}$

output $\mathrm{x}-$ output $\mathrm{y}$

$----$

1402

\section{0}

output $x$

6.089

$-189338.094$

6.274

$-186895.438$

$13020 \quad 13.537$

$-94674.781$

$13030 \quad 13.635$

$-93453.375$

15050

$-0.496$

$-273004.344$

15070

14040

0.080

$-265708.969$

6.466

$-184456.719$

14050

13040

$-182021.250$

13.728

$-92233.945$

13.826

$-91016.141$

$14060 \quad 6.856$

$-179588.312$

$14070 \quad 7.046$

$-177157.188$

$13060 \quad 13.924$

$-89799.594$

$12020 \quad 20.995$

0.000

11020

28.443

94674.781

11030

28.343

93453.375

10030 output y
----923

3851133.750

21.664

3962102.750

12.801

3849571.000

21.543

3960560.250

39.301

4186039.000

56.694

4406945.000

30.388

4072892.750

39.104

4183535.500

30.273

4071370.250

38.984

4182033.250

47.807

4294063.000

56.510

4404508.500

47.696

4292581.000

12.765

3849050.000

12.804

3849571.000

21.551

3960560.250

21.676

3962102.750 $\mathrm{x}$ erro

\begin{tabular}{rr}
\multicolumn{1}{c}{ x error } & y error \\
-8.540 & 8.723 \\
-82.383 & 21.890 \\
-17.223 & -28.940 \\
18.388 & -14.351 \\
3.485 & 54.671 \\
35.261 & -16.286 \\
-79.861 & -7.812 \\
\hline
\end{tabular}

$5.074 \quad 18.692$

$-19.506 \quad 16.370$

$16.517 \quad-44.773$

$12.496 \quad-12.357$

$\begin{array}{ll}7.806 & 45.478\end{array}$

$46.431 \quad 17.887$

$81.912 \quad-3.776$

$61.224 \quad-68.433$

$\begin{array}{ll}7.327 & 0.717\end{array}$

$-31.770 \quad 5.410$

186895.438 


\begin{tabular}{rrrrr} 
tic id & \multicolumn{1}{c}{ input $x$} & \multicolumn{1}{c}{ input $y$} & & \\
& output $x$ & \multicolumn{1}{c}{ output $y$} & x error & y error \\
\hline 9030 & 43.051 & 21.888 & & \\
& 280314.875 & 3964673.500 & 52.065 & 79.409 \\
12040 & 20.989 & 30.232 & & \\
& 0.000 & 4070862.750 & 20.510 & -43.241 \\
11040 & 28.241 & 30.280 & & \\
& 92233.945 & 4071370.250 & -64.599 & 15.404 \\
10040 & 35.499 & 30.404 & & \\
& 184456.719 & 4072892.750 & -60.823 & 30.684 \\
12060 & 20.990 & 47.656 & & \\
& 0.000 & 4292087.000 & 34.856 & -29.526 \\
11060 & 28.052 & 47.701 & & \\
& 89799.594 & 4292581.000 & -23.196 & 7.473 \\
12070 & 20.989 & 56.356 & & \\
& 0.000 & 4402558.500 & 21.361 & -40.306 \\
11070 & 27.954 & 56.402 & & \\
& 88583.961 & 4403046.000 & -50.505 & 16.423 \\
10070 & 34.928 & 56.518 & & \\
& 177157.188 & 4404508.500 & 1.098 & -8.910 \\
9040 & 42.757 & 30.609 & & \\
& 276657.156 & 4075429.750 & -27.115 & 62.199 \\
9050 & 42.473 & 39.309 & & \\
& 273004.344 & 4186039.000 & 22.629 & -82.719
\end{tabular}




\section{Appendix C: Describe output for the Arizona datasets}

\section{Description of SINGLE precision coverage AZGEOL}

\section{FEATURE CLASSES}

\begin{tabular}{|c|c|c|c|c|c|}
\hline Feature Class & Subclass & $\begin{array}{l}\text { Number of } \\
\text { Features }\end{array}$ & $\begin{array}{c}\text { Attribute } \\
\text { data (bytes) }\end{array}$ & $\begin{array}{l}\text { Spatial } \\
\text { Index? }\end{array}$ & Topology \\
\hline ARCS & & 25546 & 36 & & \\
\hline POLYGONS & & 10807 & 30 & & Yes \\
\hline NODES & & 18540 & & & \\
\hline
\end{tabular}

SECONDARY FEATURES

Tics

Arc Segments

Polygon Labels
28

393360

10806

TOLERANCES

Fuzzy $=\quad 0.879 \mathrm{~V} \quad$ Dangle $=\quad 0.100 \mathrm{~V}$

COVERAGE BOUNDARY

$\begin{array}{rrrr}\mathrm{Xmin}= & -265535.875 & \mathrm{Xmax}= & 280908.688 \\ \mathrm{Ymin}= & 3775534.000 & \mathrm{Ymax}= & 4406138.000\end{array}$

STATUS

The coverage has not been Edited since the last BUILD or CLEAN.

\section{COORDINATE SYSTEM DESCRIPTION}

Projection

Units

Spheroid

Parameters:

1st standard parallel

2nd standard parallel

central meridian

latitude of projection's origin

false easting (meters)

false northing (meters)
LAMBERT

METERS

CLARKE1866

$\begin{array}{lll}33 & 0 & 0.000\end{array}$

$\begin{array}{lll}45 & 0 & 0.000\end{array}$

$\begin{array}{lll}-112 & 0 & 0.00\end{array}$

$\begin{array}{lll}0 & 0 & 0.000\end{array}$

0.00000

0.00000 
Description of SINGLE precision coverage AZFOLD

FEATURE CLASSES

\begin{tabular}{lccccc} 
Feature Class & Subclass & $\begin{array}{c}\text { Number of } \\
\text { Features }\end{array}$ & $\begin{array}{c}\text { Attribute } \\
\text { data (bytes) }\end{array}$ & $\begin{array}{c}\text { Spatial } \\
\text { Index? }\end{array}$ & Topology? \\
\hline--------- & ------ & ------- & --------- & ----- & - \\
ARCS & & 250 & 36 & & \\
NODES & & 546 & & & \\
ANNOTATIONS & (blank) & 8 & &
\end{tabular}

SECONDARY FEATURES

Tics 28

Arc Segments 3857

TOLERANCES

Fuzzy $=\quad 62.753 \mathrm{~N} \quad$ Dangle $=\quad 0.000 \mathrm{~N}$

COVERAGE BOUNDARY

$\begin{array}{llll}X \min = & -171110.109 & \mathrm{Xmax}= & 266871.688\end{array}$

$\begin{array}{llll}\mathrm{Ymin}= & 3778380.250 & \mathrm{Ymax}= & 4405908.000\end{array}$

STATUS

The coverage has not been Edited since the last BUILD or CLEAN.

COORDINATE SYSTEM DESCRIPTION

Projection

Units

Spheroid

Parameters:

1st standard parallel

2nd standard parallel

central meridian

latitude of projection's origin

false easting (meters)

false northing (meters)
LAMBERT

METERS

CLARKE1866
$\begin{array}{lll}33 & 0 & 0.000\end{array}$
$\begin{array}{lll}45 & 0 & 0.000\end{array}$
$\begin{array}{lll}-112 & 0 & 0.00\end{array}$
$\begin{array}{lll}0 & 0 & 0.000\end{array}$
0.00000
0.00000 
Description of SINGLE precision coverage AZPTFEAT

FEATURE CLASSES

\begin{tabular}{|c|c|c|c|c|c|}
\hline Feature Class & Subclass & $\begin{array}{l}\text { Number of } \\
\text { Features }\end{array}$ & $\begin{array}{c}\text { Attribute } \\
\text { data (bytes) }\end{array}$ & $\begin{array}{l}\text { Spatial } \\
\text { Index? }\end{array}$ & Topology? \\
\hline Points & & 437 & 24 & & \\
\hline
\end{tabular}

SECONDARY FEATURES

Tics

28

TOLERANCES

Fuzzy $=\quad 47.353 \mathrm{~N} \quad$ Dangle $=\quad 0.000 \mathrm{~N}$

COVERAGE BOUNDARY

$\begin{array}{rlrr}\mathrm{Xmin}= & -144648.656 & \mathrm{Xmax}= & 273688.781 \\ \mathrm{Ymin}= & 3780243.250 & \mathrm{Ymax}= & 4253694.000\end{array}$

\section{STATUS}

The coverage has not been Edited since the last BUILD or CLEAN.

\section{COORDINATE SYSTEM DESCRIPTION}

Projection

Units

Spheroid

Parameters:

1st standard parallel

2nd standard parallel

central meridian

latitude of projection's origin

false easting (meters)

false northing (meters)
LAMBERT

METERS

CLARKE1866

$\begin{array}{lll}33 & 0 & 0.000\end{array}$

$\begin{array}{lll}45 & 0 & 0.000\end{array}$

$\begin{array}{lll}-112 & 0 & 0.00\end{array}$

$\begin{array}{lll}0 & 0 & 0.000\end{array}$

0.00000

0.00000 
Description of SINGLE precision coverage AZPTDEC

\section{FEATURE CLASSES}

\begin{tabular}{|c|c|c|c|c|c|}
\hline Feature Class & Subclass & $\begin{array}{l}\text { Number of } \\
\text { Features }\end{array}$ & $\begin{array}{c}\text { Attribute } \\
\text { data (bytes) }\end{array}$ & $\begin{array}{l}\text { Spatial } \\
\text { Index? }\end{array}$ & Topology \\
\hline Points & & 776 & 30 & & \\
\hline
\end{tabular}

SECONDARY FEATURES

Tics

28

TOLERANCES

Fuzzy $=\quad 62.518 \mathrm{~N} \quad$ Dangle $=0.000 \mathrm{~N}$

COVERAGE BOUNDARY

$\begin{array}{lllr}\mathrm{Xmin}= & -244386.234 & \mathrm{Xmax}= & 271258.750 \\ \mathrm{Ymin}= & 3779326.750 & \mathrm{Ymax}= & 4404510.500\end{array}$

$\begin{array}{llll}\mathrm{Ymin}= & 3779326.750 & \mathrm{Ymax}= & 4404510.500\end{array}$

STATUS

The coverage has not been Edited since the last BUILD or CLEAN.

\section{COORDINATE SYSTEM DESCRIPTION}

Projection

Units

Spheroid

Parameters:

1st standard parallel

2nd standard parallel

central meridian

latitude of projection's origin

false easting (meters)

false northing (meters)
LAMBERT

METERS

CLARKE1866

$\begin{array}{lll}33 & 0 & 0.000\end{array}$

$\begin{array}{lll}45 & 0 & 0.000\end{array}$

$\begin{array}{lll}-112 & 0 & 0.00\end{array}$

$\begin{array}{lll}0 & 0 & 0.000\end{array}$

0.00000

0.00000 


\section{Appendix D: Explanation of geologic map units (from Wilson and others, 1983)}

Qs - SEDIMENTARY DEPOSITS: Mainly alluvial gravel, sand, and silt in flood plains, terraces, fans, and pediment cappings but locally includes dune sand, lake deposits, and landslide masses. Shown only in areas where they are of appreciable thickness or extent.

Qb - VOLCANIC ROCKS: Basaltic flows, agglomerate, tuffs, and cinders distinguished from older basalts by recognizable cinder cones, craters, and other geomorphic evidence of recent formation.

Qr - VOLCANIC ROCKS: Rhyolitic flows and tuff resting disconformably on Qs. Recognized only in Yuma County.

Qi - DIKES AND PLUGS: Mainly basaltic in composition.

QTs - SEDIMENTARY DEPOSITS: Includes Gila Conglomerate and other stream and lake deposits mainly in intermontane areas. Consists of loosely to firmly consolidated gravel, sand, and silt, local clay, gypsum, marl, limestone, diatomite, and some intercalated basalt flows and felsic tuff beds.

QTv - VOLCANIC ROCKS: Undivided rhyolitic to andesitic flows and pyroclastic rocks; includes some plugs and dikes. Includes units interfingering with QTs and some possibly older units whose debris is in QTs.

QTb - VOLCANIC ROCKS: Basaltic flows, agglomerate, tuff, and cinders. Includes units interfingering with QTs and some possibly older units whose debris is in QTs.

QTr - VOLCANIC ROCKS: Rhyolite flows and pyroclastic rocks. Includes units interfingering with QTs and some possibly older units whose debris is in QTs.

QTi - DIKES AND PLUGS: Mainly andesitic to basaltic in composition but includes some rhyolitic intrusives in central Yuma County.

Tbs - SEDIMENTARY DEPOSITS: Sedimentary part of the Bidahochi Formation (Pliocene) in northeastern Arizona consisting of sandstone, siltstone, and locally bentonitic clay.

Tc - SEDIMENTARY DEPOSITS: Chuska Sandstone (Pliocene?) in Apache County.

Tps - SEDIMENTARY DEPOSITS: Includes: fossiliferous alluvial and lacustrine deposits of middle or early Pliocene age within valleys of the present drainage system and correlative conglomerate, sand, silt, and clay; Daniels Conglomerate of western Pima County and other unfossiliferous alluvial conglomerates that locally contain lava flows, tuffs, and breccias and interfinger with Tertiary volcanic rocks known to be younger than Tms; and terrestrial deposits tentatively correlated with the Chuska Sandstone or Bidahochi Formation.

Tms - SEDIMENTARY ROCKS: Terrestrial conglomerate, sandstone, siltstone, limestone, tuffaceous beds, and andesitic flows and breccias, including Locomotive Fanglomerate, Helmet Fanglomerate, Pantano Formation, and Whitetail Conglomerate; and fossiliferous beds in Pima and Yuma Counties known to be no older than late Oligocene or younger than middle Miocene.

Ts - SEDIMENTARY ROCKS: Mainly conglomerate, sandstone, siltstone, limestone, and tuffaceous beds but locally includes volcanic units ranging from rhyolitic to andesitic in composition.

Tv - VOLCANIC ROCKS: Rhyolitic to basaltic rocks, flows, tuffs, breccias, and agglomerates interfingering in part with Tertiary sedimentary rocks. Includes some plugs and dikes. 
Tvs - VOLCANIC ROCKS: Silicic volcanic rocks, flows, tuffs, breccias, and agglomerates interfingering in part with Tertiary sedimentary rocks. Includes some plugs and dikes.

Tvi - VOLCANIC ROCKS: Intermediate volcanic rocks, flows, tuffs, breccias, and agglomerates interfingering in part with Tertiary sedimentary rocks. Includes some plugs and dikes.

Tvm - VOLCANIC ROCKS: Mafic volcanic rocks, flows, tuffs, breccias, and agglomerates interfingering in part with Tertiary sedimentary rocks. Includes some plugs and dikes.

Ti - DIKES, SILLS, AND PLUGS: Rhyolitic to basaltic in composition.

TKs - SEDIMENTARY ROCKS: Includes Cloudburst Formation in Pinal County and unnamed shale, sandstone, conglomerate, and limestone units in southern and western parts of the State; locally contains volcanic rocks.

TKv - VOLCANIC ROCKS: Andesitic to rhyolitic in composition, including flows, pyroclastic rocks, and associated conglomerates consisting largely of volcanic debris. Where in contact with penecontemporaneous intrusive rocks (TKg, TKdi, TKi), the intrusive rocks generally cut the volcanic rocks.

TKa - VOLCANIC ROCKS: Predominantly andesitic in composition, including flows, pyroclastic rocks, and associated conglomerates consisting largely of volcanic debris. Where in contact with penecontemporaneous intrusive rocks (TKg, TKdi, TKi), the intrusive rocks generally cut the volcanic rocks.

$\mathrm{TKr}$ - VOLCANIC ROCKS: Predominantly rhyolitic in composition, including flows, pyroclastic rocks, and associated conglomerates consisting largely of volcanic debris. Where in contact with penecontemporaneous intrusive rocks (TKg, TKdi, TKi), the intrusive rocks generally cut the volcanic rocks.

TKg - INTRUSIVE ROCKS: Granite, quartz monzonite, granodiorite, quartz diorite, and some porphyry equivalents of these rocks

TKdi - INTRUSIVE ROCKS: Diorite; includes laccoliths of diorite porphyry in Carrizo Mountains

TKi - INTRUSIVE ROCKS: Granitic, dioritic, rhyolitic, and andesitic dikes, sills, and plugs.

TKsc - METAMORPHIC ROCKS: schist and phyllite

TKgn - METAMORPHIC ROCKS: Gneiss derived mainly from intrusive rocks of early Tertiary and Late Cretaceous age but locally includes phases derived from sedimentary and igneous rocks ranging in age from Precambrian through Cretaceous in eastern Pima County.

Kmv - MESAVERDE GROUP: In Black Mesa area includes Yale Point Sandstone, Wepo Formation, and Toreva Formation

Km - MANCOS SHALE

Kd - DAKOTA SANDSTONE

Kus - SEDIMENTARY ROCKS: Includes Pinkard Formation in Greenlee County and probably equivalent beds in Graham and Pinal Counties. Upper Cretaceous beds in the Santa Rita Mountains are included with undivided Cretaceous rocks (Ks).

Kls - SEDIMENTARY ROCKS: Includes Bisbee Group in the southeastern part of the State; in northern Cochise County also includes underlying Jurassic(?) or Triassic(?) volcanic rocks.

Ks - SEDIMENTARY AND VOLCANIC ROCKS: Includes Amole Arkose and Recreation Red Beds of Brown (1939) and other units of known or supposed Cretaceous age. 
Kv - VOLCANIC ROCKS: Rhyolitic to andesitic flows and tuffs.

Kr - VOLCANIC ROCKS: Predominantly rhyolitic flows and tuffs

Ka - VOLCANIC ROCKS: Predominantly andesitic flows and tuffs

Kvs - SEDIMENTARY AND VOLCANIC ROCKS: Intercalated sedimentary and rhyolitic to andesitic volcanic rocks.

Jm - MORRISON FORMATION: Mapped with San Rafael Group south of latitude 3550' north.

Jsr - SAN RAFAEL GROUP: Includes Bluff and Cow Springs Sandstones, Summerville Formation, Todilto Limestone, and Entrada Sandstone of Late Jurassic age, and Carmel Formation of Late and Middle Jurassic age.

JTRgc - GLEN CANYON GROUP: Includes Navajo Sandstone (Jurassic and Triassic?), Kayenta Formation (Upper Triassic?), Moenave Formation (Upper Triassic?), and Wingate Sandstone (Upper Triassic).

JTRg - INTRUSIVE ROCKS: Granite, quartz monzonite, alaskite, and granitic to monzonitic porphyries.

TRc - CHINLE FORMATION

TRcs - CHINLE FORMATION: Shinarump Member of Chinle Formation mapped separately north of latitude $35^{\circ} 10^{\prime}$ north.

TRm - MOENKOPI FORMATION: Includes Hoskinnini. Member of Triassic(?) age in Monument Valley area.

MZsc - MESOZOIC METAMORPHIC ROCKS: Schist and phyllite derived from Mesozoic sedimentary rocks.

MZgn - MESOZOIC METAMORPHIC ROCKS: Gneiss

MZgr - MESOZOIC GRANITE TO QUARTZ DIORITE

MZv - MESOZOIC VOLCANIC ROCKS: Rhyolitic to andesitic flows and pyroclastic rocks; locally includes interfingering shale, sandstone, and conglomerate. Includes units known to predate Lower Cretaceous rocks in the Huachuca and Patagonia Mountains.

MZs - MESOZOIC SEDIMENTARY ROCKS: Includes limestone, shale, and sandstone, and conglomerate; locally metamorphosed.

MZPZs - MESOZOIC AND PALEOZOIC SEDIMENTARY ROCKS: Mesozoic and Paleozoic sedimentary rocks undivided

Pkt - KAIBAB LIMESTONE AND TOROWEAP FORMATION

Pc - COCONINO SANDSTONE

Pdc - DE CHELLY SANDSTONE

Pct - CUTLER FORMATION: Includes De Chelly Sandstone Member, Organ Rock Tongue, Cedar Mesa Sandstone Member, and Halgaito Tongue in the Monument Valley area.

Ph - HERMIT SHALE

PPPn - NACO GROUP UNDIVIDED 
Pnu - NACO GROUP UPPER FORMATIONS: Includes Rainvalley Formation, Concha Limestone, and Scherrer Formation.

PPPnl - NACO GROUP LOWER FORMATIONS: Includes Epitaph Dolomite (Permian), Colina Limestone (Permian), Earp Formation (Permian and Upper Pennsylvanian), and Horquilla Limestone (Pennsylvanian). Also includes the Naco Formation as used in central Arizona.

PPPs - SUPAI FORMATION

PPPc - PAKOON AND CALLVILLE LIMESTONES: Pakoon Limestone (Permian) and Callville Limestone (Pennsylvanian) of McNair (1951) undivided.

PZs - PALEOZOIC SEDIMENTARY ROCKS: Paleozoic sedimentary rocks undivided

MDs - SEDIMENTARY ROCKS: Includes Upper Mississippian Paradise Formation of Stoyanow (1926) and Hernon (1935) in extreme southeastern Arizona; Escabrosa Limestone (Upper and Lower Mississippian) and Martin Formation (Devonian) in much of southern and central Arizona; Redwall Limestone (Mississippian) and Temple Butte Limestone (Upper? Devonian) in northern Arizona; Modoc Limestone (Lower Mississippian) and Morenci Shale (Upper Devonian) in western Greenlee County; and locally Pennsylvanian limestone.

Ocs - SEDIMENTARY ROCKS: Includes Longfellow Limestone (Lower Ordovician and Upper Cambrian) and Coronado Quartzite (Upper Cambrian) in Greenlee County; El Paso Limestone (Lower Ordovician), Abrigo Formation (Upper and Middle Cambrian), and Bolsa Quartzite (Middle Cambrian) in eastern Cochise County; Abrigo Formation and Bolsa Quartzite in western Cochise, Graham, Pima, Santa Cruz, Pinal, Gila, and Maricopa Counties; Tonto Group (Middle and Lower Cambrian) in northern and central Arizona; and Ordovician(?) and Cambrian limestone and dolomite in northwestern Mohave County.

pCdb - DIABASE: Locally includes post-Precambrian diabase.

pCt - TROY QUARTZITE: Locally may contain Cambrian sandstone and quartzite.

pCg - GRAND CANYON SERIES: Includes Chuar and Unkar Groups.

pCa - APACHE GROUP: Includes Mescal Limestone and associated basalt flows, Dripping Spring Quartzite, and Pioneer Shale.

pCgr - INTRUSIVE ROCKS: Granite, quartz monzonite, granodiorite, and quartz diorite. Locally includes areas of granitic rocks and other igneous rocks of post-Paleozoic age.

pCdi - INTRUSIVE ROCKS: Diorite, diorite porphyry, and gabbro.

pCpy - INTRUSIVE ROCKS: Pyroxenite.

pCm - MAZATZAL QUARTZITE: Locally includes Deadman Quartzite and Maverick Shale of Wilson (1939).

pCry - RHYOLITE: Mainly flows and intrusive material but includes minor amounts of agglomerate and breccia.

pCsc - METAMORPHOSED SEDIMENTARY AND VOLCANIC ROCKS: Includes Vishnu Schist in Grand Canyon area, Yavapai Series in central Arizona, Pinal Schist in southeastern Arizona, and unnamed schistose units. Mainly phyllite, slate, mica schist, chlorite schist and amphibolite derived from interbedded shale, sandstone, and rhyolitic to basaltic flows and tuffs but locally includes intrusive rhyolite, diorite, gabbro, and pyroxenite. 
pCgs - METAMORPHOSED SEDIMENTARY AND VOLCANIC ROCKS: Mainly nonfoliated greenstone units derived from metamorphism of mafic flows and intrusive rocks. Mainly phyllite, slate, mica schist, chlorite schist and amphibolite derived from interbedded shale, sandstone, and rhyolitic to basaltic flows and tuffs but locally includes intrusive rhyolite, diorite, gabbro, and pyroxenite.

pCgn - METAMORPHOSED SEDIMENTARY AND VOLCANIC ROCKS: Gneiss; includes some areas of undivided schist and granite. Mainly phyllite, slate, mica schist, chlorite schist and amphibolite derived from interbedded shale, sandstone, and rhyolitic to basaltic flows and tuffs but locally includes intrusive rhyolite, diorite, gabbro, and pyroxenite.

\section{References Cited in Explanation}

Brown, W. H., 1939, Tucson Mountains, an Arizona basin and range type: Geol. Soc. America Bull., v. 50 p. $697-$ 760.

Hernon, R. M., 1935, The Paradise formation and its fauna: Jour. Paleontology, v. 9, p. 653-696.

McNair, A. H., 1951, Paleozoic stratigraphy of part of northwestern Arizona: Am. Assoc. Petroleum Geologists Bull., v. 35, p. 503-541

Stoyanow, A. A., 1926, Notes on recent stratigraphic work in Arizona: Am. Jour. Sci., 5th ser., v. 12, p. 311-324.

Wilson, E. D., 1939, Precambrian Mazatzal revolution in central Arizona: Geol. Soc. America Bull., v. 50, p. 11131164. 


\title{
Appendix E: Sources for the Geologic Map of Arizona (from Wilson and others, 1983)
}

\author{
(keyed to Figure E1)
}

Source citations have been locally modified or adjusted by the authors or by collaborating members of the staff of the U. S. Geological Survey.

* indicates published.

+ indicates unpublished map made for use in compiling county map or maps published by the Arizona Bureau of Mines, 1957-60.

1. Akers, J. P., 1964, U.S. Geological Survey Water-Supply Paper 1771

2. Allen, J. E., and Balk, Robert, 1954, New Mexico Bureau of Mines and Mineral Resources Bulletin 36.

3. Anderson, C. A., and Creasey, S. C., 1958, U.S., Geological Survey Professional Paper 308

4. Anderson, C. A., Scholz, E. A., and Strobell, J. D., Jr., 1955, U.S. Geological Survey Professional Paper 278.

5. Blissenbach, Erich, 1952, Plateau, v. 24, no. 4.

6. Bromfield, C. S., and Shride, A. F., 1956, U.S. Geological Survey Bulletin 1027-N.

7. Brown, W. H., 1939, Geological Society of America Bulletin, v. 50, no. 5.

8. Bryant, D. L., 1951, University of Arizona, master's thesis *.

9. Cooley, M. E., 1960, Geochronology Laboratories, University of Arizona, open-file map.

10. Cooper, J. R., 1959, U.S. Geological Survey Mineral Investigations Field Studies Map MF-213.

11. Cooper, J. R., 1960, U.S. Geological Survey Mineral Investigations Field Studies Map MF-231.

12. Cooper, J. R., U.S. Geological Survey reconnaissance mapping + .

13. Cooper, J. R., U.S. Geological Survey *: preliminary map of part of area in Cooper, J. R., 1960, U.S. Geological Survey Bulletin 1112-C.

14. Cooper, J. R., and Silver, L. T., 1964, U.S. Geological Survey Professional Paper 416.

15. Cosner, O. J., Armstrong, C. A., and Page, H. G., U.S. Geological Survey *.

16. Cosner, O. J., and Page, H. G., U.S. Geological Survey*.

17. Creasey, S. C., 1966, U.S. Geological Survey Miscellaneous Geological Investigations Map I-470.

18. Creasey, S. C., Jackson, E. D., and Gulbrandsen, R. A., 1961, U.S. Geological Survey Map MF-238; part of area published in detail in Creasey, S. C., 1967, U.S. Geological Survey Bulletin 1218.

19. Darton, N. H., 1925, Arizona Bureau of Mines Bulletin 119.

20. Dings, M. G., 1951, U.S. Geological Survey Bulletin 978-E.

21. Drewes, Harold, 1966, U.S. Geological Survey open-file map.

22. Epis, R. C., 1956, University of California doctoral dissertation *.

23. Fair, C. L., and Krutz, W. I., 1959, Arizona Geological Society Guidebook 2, Southern Arizona.

24. Finnell, T. L., 1966, U.S. Geological Survey Geological Quadrangle Maps GQ-544, GQ-545.

25. Gastil, Gordon, 1958, Geological Society of America Bulletin, v. 69, no. 12, pt. 1.

26. Gilluly, James, 1946, U.S. Geological Survey Professional Paper 209.

27. Gilluly, James, 1956, U.S. Geological Survey Professional Paper 281.

28. Hargraves, R. B., Newmont Exploration, Ltd. *.

29. Harshbarger, J. W., 1961, U.S. Geological Survey open-file maps.

30. Hayes, P. T., and Raup, R. B., 1968 U.S. Geological Survey Miscellaneous Geological Investigations Map I-509.

31. Heindl, L. A., U.S. Geological Survey *.

32. Heindl, L. A., and others U.S. Geological Survey*.

33. Hughes, P. W., 1950, University of Arizona master's thesis *.

34. Jaggar, T. A., Jr., and Palache, Charles, 1905, U.S. Geological Survey Geological Atlas, Folio 126.

35. Jerome, S. E., 1955, University of Utah doctoral dissertation *.

36. Johnson, P. W., 1962, U.S. Geological Survey Water-Supply Paper 1539-S.

37. Johnston, W. P., 1955, University of Utah, doctoral dissertation *.

38. Jones, W. R., Bowles, C. G., and Hedlund, D. C., U.S. Geological Survey reconnaissance mapping + .

39. Krieger, M. H., 1965, U.S. Geological Survey Professional Paper 467.

40. Krieger, M. H., Reconnaissance mapping in part published as U.S. Geological Survey Maps I 501 to I 505 (1967).

41. Krieger, M. H., U.S. Geological Survey*.

42. Lasky, S. G., and Webbe4r, B. N., 1949, U.S. Geological Survey Bulletin 961. 
43. Lehner, R. E., 1958, U.S. Geological Survey Bulletin 1021-N.

44. Lindgren, Waldemar, 1905, U.S. Geological Survey Geological Atlas, Folio 129.

45. Longwell, C. R., 1936, Geological Society of America Bulletin, v. 47, no. 9.

46. McClymonds, N. E., and Ruff, A. W., 1959, Arizona Geological Society Guidebook 2, Southern Arizona.

47. Mayo, E. B., and others, University of Arizona *.

48. Moore, B.N., Tolman, C. F., Butler, B. S., and Hermon, R. M., 1941, U.S. Geological Survey open-file map.

49. Moore, R.T., Arizona Bureau of Mines reconnaissance mapping +.

50. Moore, R.T., and Peirce, H. W., Arizona Bureau of Mines reconnaissance mapping +.

51. Moore, R.T., and Wrucke, C.T., Arizona Bureau of Mines and U.S. Geological Survey reconnaissance mapping +.

52. Nobel, L. F., 1914, U.S. Geological Survey Bulletin 549.

53. Page, H. G., Ellis, J. M., and Heindl, L. A., U.S. Geological Survey *.

54. Peirce, H. W., Arizona Bureau of Mines reconnaissance mapping +.

55. Peterson, D. W., 1960, U.S. Geological Survey Geological Quadrangle Map GQ-128.

56. Peterson, D. W., 1962, U.S. Geological Survey Mineral Investigations Field Studies Map MF-253.

57. Peterson, N. P., 1962, U.S. Geological Survey Professional Paper 342.

58. Peterson, N. P., 1963, U.S. Geological Survey Bulletin 1141-H.

59. Ransome, F. L., 1904, U.S. Geological Survey Professional Paper 21.

60. Ransome, F. L., 1919, U.S. Geological Survey Professional Paper 115.

61. Ransome, F. L., 1923, U.S. Geological Survey Bulletin 743.

62. Raup, R. B., Jr., U.S. Geological Survey *.

63. Rehkemper, L. J., and Rutledge, F. W., 1956, University of Texas, master's theses *.

64. Richard, K. E., and Courtright, J. H., 1954, Mining Engineering, v. 6, no. 11.

65. Sabins, F. F., Jr., 1957, Geological Society of America Bulletin, v. 68, no. 10.

66. Shride, A. F., and Wrucke, C. T., U.S. Geological Survey *.

67. Simons, F. S., 1964, U.S. Geological Survey Professional Paper 461.

68. Simons, F. S., U.S. Geological Survey *.

69. Strobell, J. D., Jr., 1956, U.S. Geological Survey Oil and Gas Investigations Map OM-160.

70. Twenter, F. R., and Metzger, D. G., 1963, U.S. Geological Survey Bulletin 1177.

71. Wargo, J. G., and Kurtz, W. L., 1956, Ohio Journal of Science, v. 56, no. 1.

72. Willden, Ronald, 1964, U.S. Geological Survey Bulletin 1161-E.

73. Wilson, E.D., Arizona Bureau of Mines reconnaissance mapping +.

74. Wilson, E.D., and Heindl, L. A., Arizona Bureau of Mines and U.S. Geological Survey reconnaissance mapping +.

75. Wilson, E. D., and Moore, R. T., Arizona Bureau of Mines reconnaissance mapping +.

76. Wilson, E. D., and O'Haire, R. T., Arizona Bureau of Mines reconnaissance mapping +.

77. Wilson, E. D., and Peirce, H. W., Arizona Bureau of Mines reconnaissance mapping +.

78. Witkind, I. J., and Thaden, R. E., U.S. Geological Survey Bulletin 1103.

79. Wrucke, C. T., 1961, U.S. Geological Survey Bulletin 1121-H.

80. Wrucke, C. T., U.S. Geological Survey reconnaissance mapping +. 


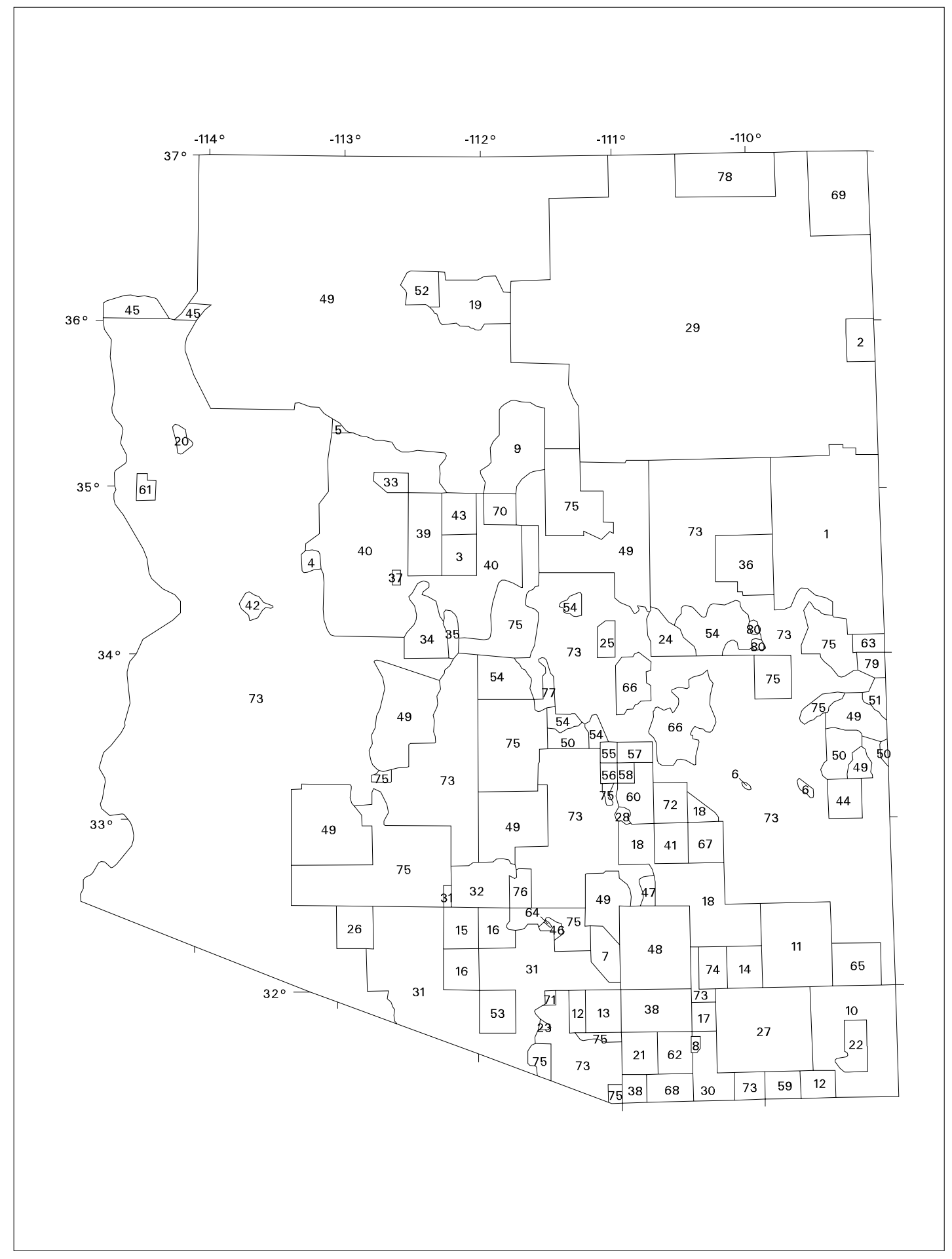

Figure E1: Sources Index Map 


\section{Appendix F: Metadata (az500k.met)}

Metadata:

Identification_Information:

Citation:

Citation_Information:

Originator: Douglas M. Hirschberg

Originator: G. Stephen Pitts

Publication_Date: 2000

Title: Digital geologic map of Arizona: a digital database derived from the 1983 printing of the

Wilson, Moore, and Cooper 1:500,000-scale map

Edition: Digital Version 1.0

Geospatial_Data_Presentation_Form: map

Series_Information:

Series_Name: USGS Open-File Report

Issue_Identification: OFR 00-409

Publication_Information:

Publication_Place: Menlo Park, California

Publisher: U.S. Geological Survey

Online_Linkage: URL=http://geopubs.wr.usgs.gov/open-file/of00-409/

Description:

Abstract:

The Geologic Map of Arizona was compiled at a scale of 1:500,000 by Eldred D. Wilson, Richard T. Moore and John R. Cooper, in 1969 and reprinted in 1977, 1981, and 1983.

Comparison of an acetate copy of the 1983 map with existing paper copies of earlier maps shows some updating of the original by 1983 . This 1983 acetate was scanned and vectorized by Optronics Specialty Co., Inc. in 1998, and put into an Arc/Info geographic information system (GIS).

The digital geologic map database can be queried in many ways to produce a variety of derivative geologic maps.

Original Publication:

Geologic Map of Arizona

by: Eldred D. Wilson, Richard T. Moore, and John R. Cooper

Digitizers: Optronics Specialty Co., Inc, and Douglas M. Hirschberg

Digital Version of:

Geologic map of Arizona, 1:500,000, 1983 printing

by: Eldred D. Wilson, Richard T. Moore, and John R. Cooper

Digital Database by Douglas M. Hirschberg and G. Stephen Pitts

Purpose:

This database was developed to provide a GIS of the geologic

map of the State of Arizona for use at a scale of

1:500,000 or smaller. This GIS is intended for use in

future spatial analysis by a variety of users.

The geologic unit descriptions for this map may be updated 
to reflect more current description of structures and the geochronology of the map units.

This database is not meant to be used or displayed at any scale larger than 1:500,000 (e.g., 1:100,000 or $1: 24,000)$

Supplemental_Information:

This GIS database consists of 4 Arc/Info datasets:

one line and polygon file (azgeol)

containing geologic contacts and structures (lines)

and geologic map rock units (polygons),

one line file (azfold) containing the folds and

crater boundaries,

one point file (azptfeat) containing geologic features,

cinder cones and diatremes.

one point file (azptdec) containing decorations, and

Time_Period_of_Content:

Time_Period_Information:

Single_Date/Time:

Calendar_Date: 2000

Currentness_Reference: Publication Date of Open-File Report 00-409

Status:

Progress: Complete

Maintenance_and_Update_Frequency: Uncertain

May update newer structure and geochronology in future

Spatial_Domain:

Bounding_Coordinates:

West_Bounding_Coordinate: -115.00

East_Bounding_Coordinate: -108.75

North_Bounding_Coordinate: 37.00

South_Bounding_Coordinate: 31.25

Keywords:

Theme:

Theme_Keyword_Thesaurus: none

Theme_Keyword: geology

Theme_Keyword: geologic map

Place:

Place_Keyword_Thesaurus: none

Place_Keyword: Arizona

Access_Constraints: none

Use_Constraints:

These data are not to be used at scales greater than 1:500,000.

Any hardcopies utilizing these data sets shall clearly indicate their source. If the user has modified the data in any way they are obligated to describe the types of modifications they have performed on the hardcopy map. User specifically agrees not to misrepresent these data sets, nor to imply that changes they made were approved by the U.S. Geological Survey. 


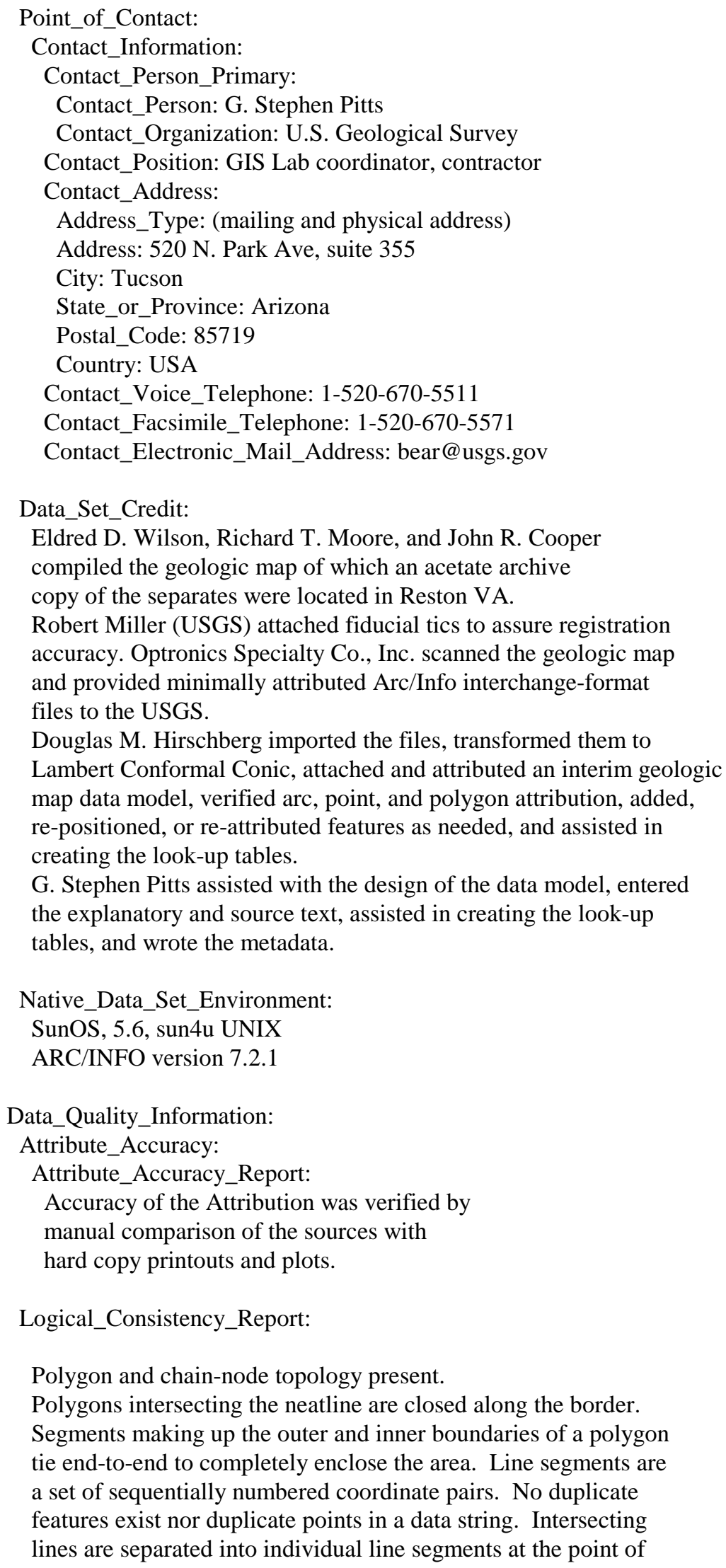


intersection. All nodes are represented by a single coordinate pair which indicates the beginning or end of a line segment.

The map boundary came from the scan, was projected to Lambert Conformal Conic.

Completeness_Report:

The digital dataset was produced from a previously published map (Wilson, Moore, \& Cooper, 1969) which is considered to be a high quality cartographic product, generally speaking contacts exist where mapped, and the best available at 1:500,000. From subsequent mapping, errors are known to exist with the structure and geochronology.

Positional_Accuracy:

Horizontal_Positional_Accuracy:

Horizontal_Positional_Accuracy_Report:

The horizontal positional accuracy for the digital data may be no better than $+/-500$ meters ( $1 \mathrm{~mm}$ at mapscale). It was tested by visual comparison of the source acetate and available paper maps with hard copy plots.

\section{Lineage:}

Source_Information:

Source_Citation:

Citation_Information:

Originator: Eldred D. Wilson, Richard T. Moore, John R. Cooper

Publication_Date: 1983

Title: Geologic Map of Arizona

Geospatial_Data_Presentation_Form: map

Series_Information:

Series_Name: map series: G

Issue_Identification: 81036

Publication_Information:

Publication_Place: Reston, VA

Publisher: U.S. Geological Survey

Source_Scale_Denominator: 500000

Type_of_Source_Media: acetate separate

Source_Time_Period_of_Content:

Time_Period_Information:

Single_Date/Time:

Calendar_Date: 1983

Source_Currentness_Reference: 1983, date of publication

Source_Citation_Abbreviation: Wilson and others (1983)

Source_Contribution: geologic units, contact, and structure

Process_Step:

Process_Description:

The original separates for this map were not locatable in Menlo Park, CA, and after extensive search, thought to no longer exist. By thorough investigation, two separates, the water layer and the geologic units, were found in a map tube in Reston, VA., and forwarded to Menlo Park, CA. where Robert Miller attached Lat-Lon tics to the acetate layer of the geologic units to assure registration accuracy 
Process_Date: 1998

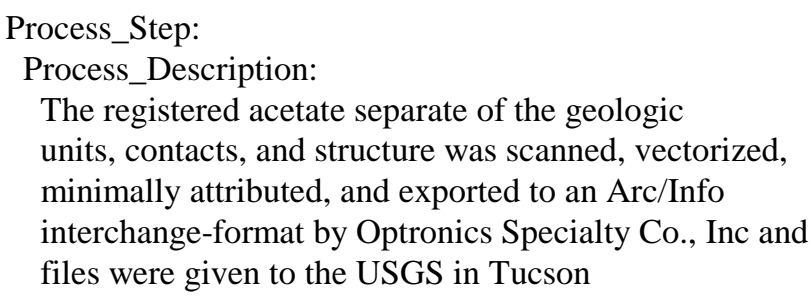

Process_Date: 1998

Process_Step:

Process_Description:

The four coverages were transformed to Lambert Conformal Conic projection using 28 tics which produced an RMS error of 0.004. All linework, points, and attributions were verified by extensively comparison between printed versions of the map, the 1983 source acetate, and hard copy plots derived from the database. Some very small polygons were not identifiable on the original printed maps or the acetate, and were eliminated. Some small polygons were missing from the initial capture, and were re-captured by D.M. Hirschberg.

All faults were attributed as Throw Unknown, Normal, Thrust, or Strike Slip, as determined from visual inspection of attributions on the paper map. Faults where attributed, were identified as U/D, T, or, in two cases on the 1983 map, with the right lateral strike slip decoration. Sense of up or down was determined by placement of the letters $U$ and D on the paper map. Sense of upper plate, lower plate for thrust faults was inconsistent, ( $\mathrm{T}$ on side of older rock in some cases and on side of younger rocks in other), so no upper plate / lower plate attribution was made on the Trust faults.

All coverages and associated files and macros are included in the Open-File Report 00-409, available on the internet at http://geopubs.wr.usgs.gov/open-file/of00-409

Process_Date: 1999

Spatial_Data_Organization_Information:

Direct_Spatial_Reference_Method: Vector

Point_and_Vector_Object_Information:

SDTS_Terms_Description:

SDTS_Point_and_Vector_Object_Type: Point

Point_and_Vector_Object_Count: 10803

SDTS_Terms_Description:

SDTS_Point_and_Vector_Object_Type: String

Point_and_Vector_Object_Count: 25546

SDTS_Terms_Description:

SDTS_Point_and_Vector_Object_Type: GT-polygon composed of chains 
Point_and_Vector_Object_Count: 10807

Spatial_Reference_Information:

Horizontal_Coordinate_System_Definition:

Planar:

Map_Projection:

Map_Projection_Name: Lambert Conformal Conic

Lambert_Conformal_Conic:

Standard_Parallel: $\quad 33$

Standard_Parallel: $\quad 45$

Longitude_of_Central_Meridian: -112

Latitude_of_Projection_Origin: 0

False_Easting: 0.00000

False_Northing: 0.00000

Planar_Coordinate_Information:

Planar_Coordinate_Encoding_Method: coordinate pair

Coordinate_Representation:

Abscissa_Resolution: 25.39368057251

Ordinate_Resolution: 25.39368057251

Planar_Distance_Units: Meters

Geodetic_Model:

Horizontal_Datum_Name: North American Datum of 1927

Ellipsoid_Name: Clarke 1866

Semi-major_Axis: 6378206.4

Denominator_of_Flattening_Ratio: 294.98

Entity_and_Attribute_Information:

Overview_Description:

Entity_and_Attribute_Overview:

The 'Digital Geologic Map of Arizona; a digital database from the 1983 printing of the Eldred D. Wilson and

Richard T. Moore, and John R. Cooper 1:500,000-scale map'

Open-File Report 00-409 contains a detailed description

of each attribute code and a reference to the associated

map symbols on the map source materials.

This GIS database consists of four Arc/Info datasets:

one line and polygon file, azgeol,

containing geologic contacts and structures (lines)

and geologic map rock units (polygons),

one line file, azfold, containing the folds and

crater boundaries,

one point file, azptfeat, containing geologic features, cinder cones and diatremes, and

one point file, azptdec, containing decorations.

Azgeol contains an arc attribute table, azgeol.aat, which relates geologic linework arc attribution to the contact look-up table, azgeol.con, the structural attribute table, azgeol.str and the source reference look-up table, sources.ref. Azgeol also contains a polygon attribute table, azgeol.pat, which relates the polygons to the rock-unit look-up table, azgeol.ru, and the source reference look-up table, sources.ref.

Azfold contains an arc attribute table, azfold.aat, which relates to the structural attribute table, azfold.str, and 
the source reference look-up table, sources.ref.

Azptfeat contains the point attribute table, azptfeat.pat, which relates the feature points to their descriptions in azptfeat.lut, and the source reference look-up table, sources.ref.

Azptdec contains the point attribute table, azptdec.pat, which relates the points to descriptions in the look-up table,

azptdec.lut, and the source reference look-up table, sources.ref.

Entity_and_Attribute_Detail_Citation

A detailed description of the items in the Arizona 500K GIS database is given in the text of the Open-File Report 00-409

available in Adobe Acrobat PDF format on the World Wide Web

at http://geopubs.wr.usgs.gov/open-file/of00-409

Distribution_Information:

Distributor:

Contact_Information:

Contact_Organization_Primary:

Contact_Organization: U.S. Geological Survey Information Services

Contact_Address:

Address_Type: mailing and physical address

Address: Open-File Reports, Box 25286

City: Denver

State_or_Province: CO

Postal_Code: 80225

Country: USA

Contact_Voice_Telephone: 1-303-202-4200

Contact_Facsimile_Telephone: 1-303-202-4693

Contact_Information:

Contact_Person_Primary:

Contact_Person: G. Stephen Pitts

Contact_Organization: U.S. Geological Survey

Contact_Position: GIS Lab coordinator

Contact_Address:

Address_Type: (mailing and physical address)

Address: 520 N. Park Ave, suite 355

City: Tucson

State_or_Province: Arizona

Postal_Code: 85719

Country: USA

Contact_Voice_Telephone: 1-520-670-5511

Contact_Facsimile_Telephone: 1-520-670-5571

Contact_Electronic_Mail_Address: bear@usgs.gov

Distribution_Liability:

The U.S. Geological Survey (USGS) provides these geographic data "as is." The USGS makes no guarantee or warranty concerning the accuracy of information contained in the geographic data. The USGS further makes no warranties, either expressed or implied as to any other matter whatsoever, including, without limitation, the condition of the product, or its fitness for any particular purpose. The burden for determining fitness for use lies entirely with the user. Although these data have been processed 
successfully on computers at the USGS, no warranty, expressed or implied, is made by the USGS regarding the use of these data on any other system, nor does the fact of distribution constitute or imply any such warranty.

In no event shall the USGS have any liability whatsoever for payment of any consequential, incidental, indirect, special, or tort damages of any kind, including, but not limited to, any loss of profits arising out of use of or reliance on the geographic data or arising out of the delivery, installation, operation, or support by USGS.

This digital geologic map GIS of the Geologic Map of Arizona at a scale of 1:500,000, is not meant to be used or displayed at any scale larger than 1:500,000 (e.g., 1:62,500 or 1:24,000).

Metadata_Reference_Information:

Metadata_Date: 19990924

Metadata_Review_Date: 19990911

Metadata_Future_Review_Date: 19990925

Metadata_Contact:

Contact_Information:

Contact_Organization_Primary:

Contact_Organization: U.S. Geological Survey

Contact_Person: G. Stephen Pitts

Contact_Position: GIS lab manager, contractor

Contact_Address:

Address_Type: mailing and physical address

Address: 520 N. Park Ave, suite 355

City: Tucson

State_or_Province: Arizona

Postal_Code: 85719

Country: United States of America

Contact_Voice_Telephone: 520.670 .5511

Contact_Facsimile_Telephone: 520.670.5571

Contact_Electronic_Mail_Address: bear@usgs.gov

Metadata_Standard_Name: FGDC Content Standards for Digital Geospatial Metadata

Metadata_Standard_Version: FGDC-STD-001-1998

Metadata_Access_Constraints: none

Metadata_Use_Constraints:

This GIS is not meant to be used or displayed at any scale larger than 1:500,000 (e.g., 1:100,00 or 1:24,000). 


\section{Appendix G: Arc/Info macro language program used to import the Arizona datasets (import.aml)}

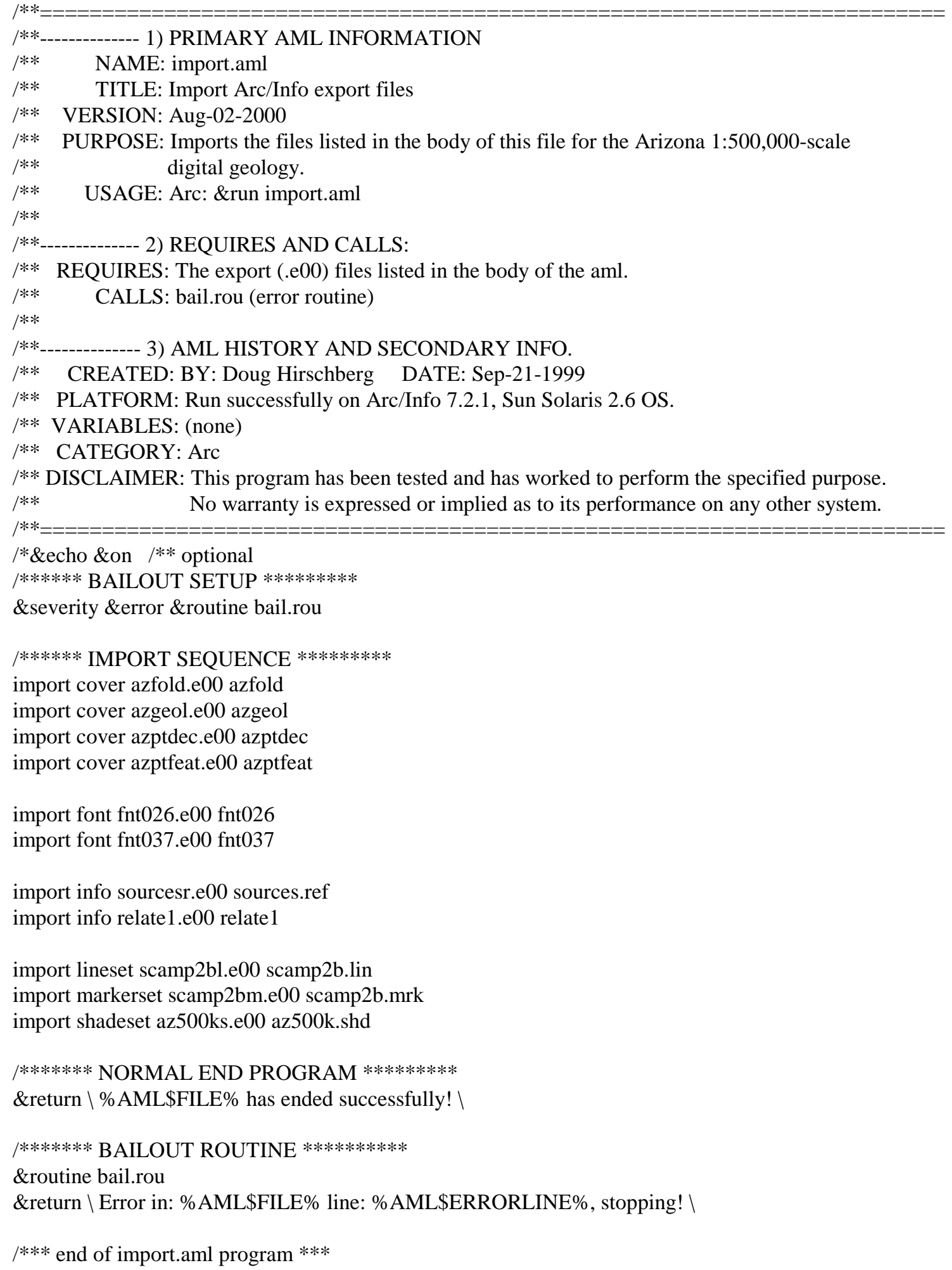




\section{Appendix H: Arc/Info macro language programs used to create graphics files for viewing and printing maps of the Arizona datasets (sheet1.aml, sheet2.aml, sheet3.aml)}

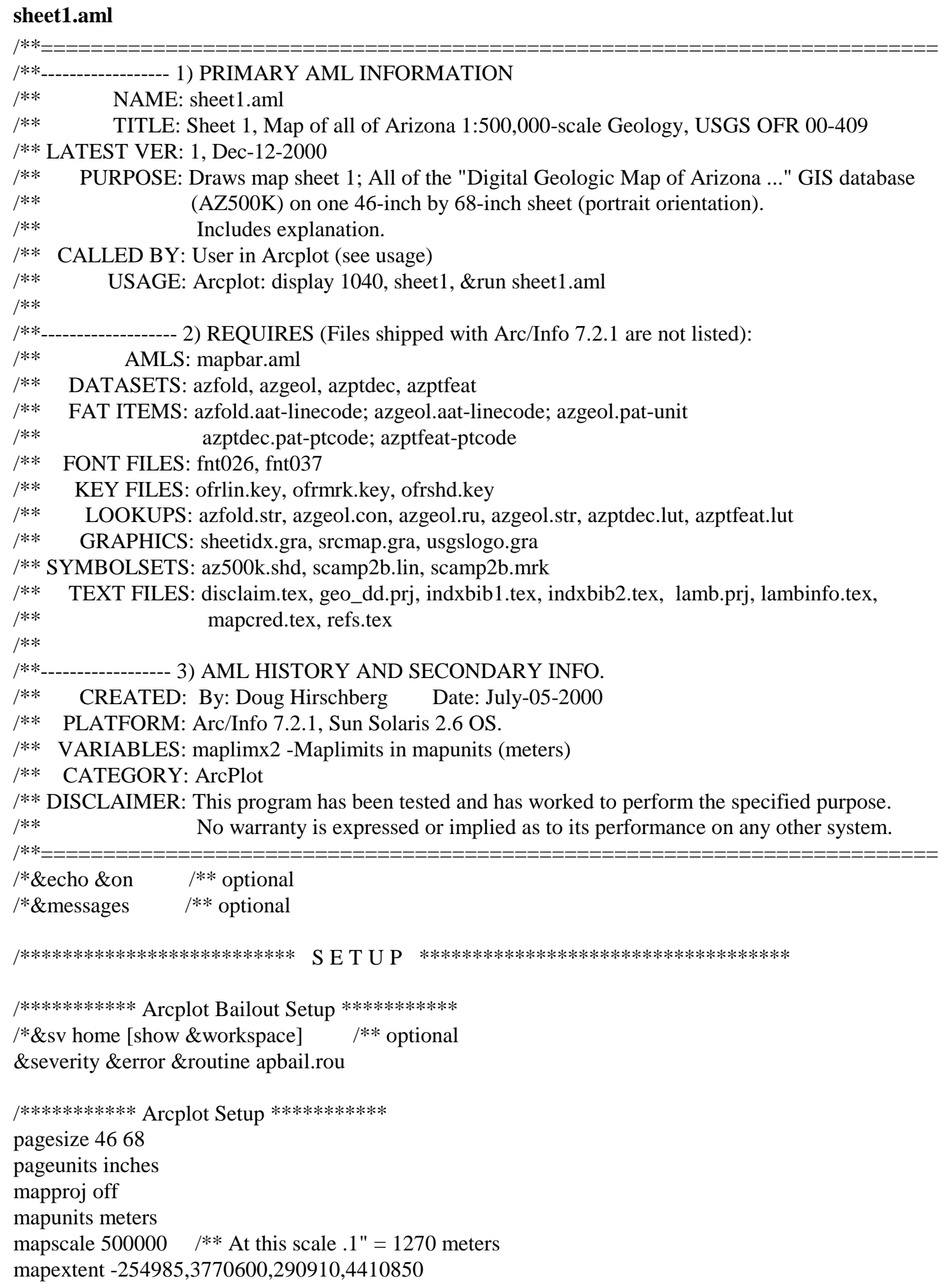




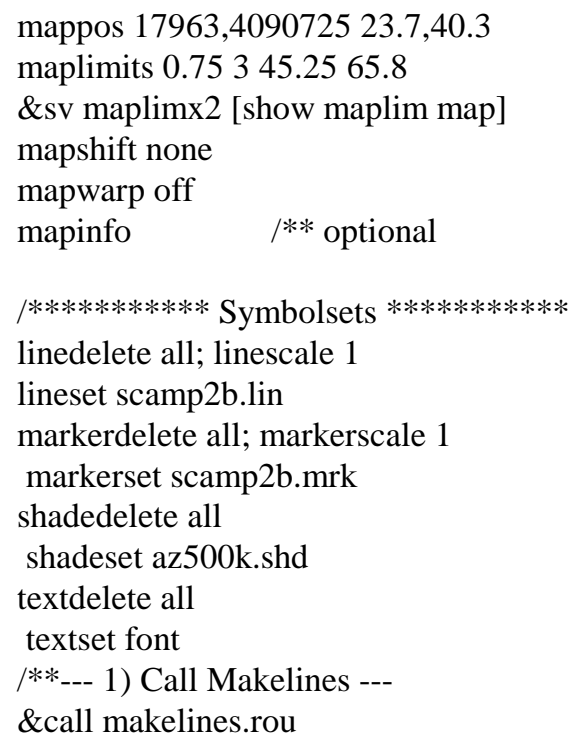




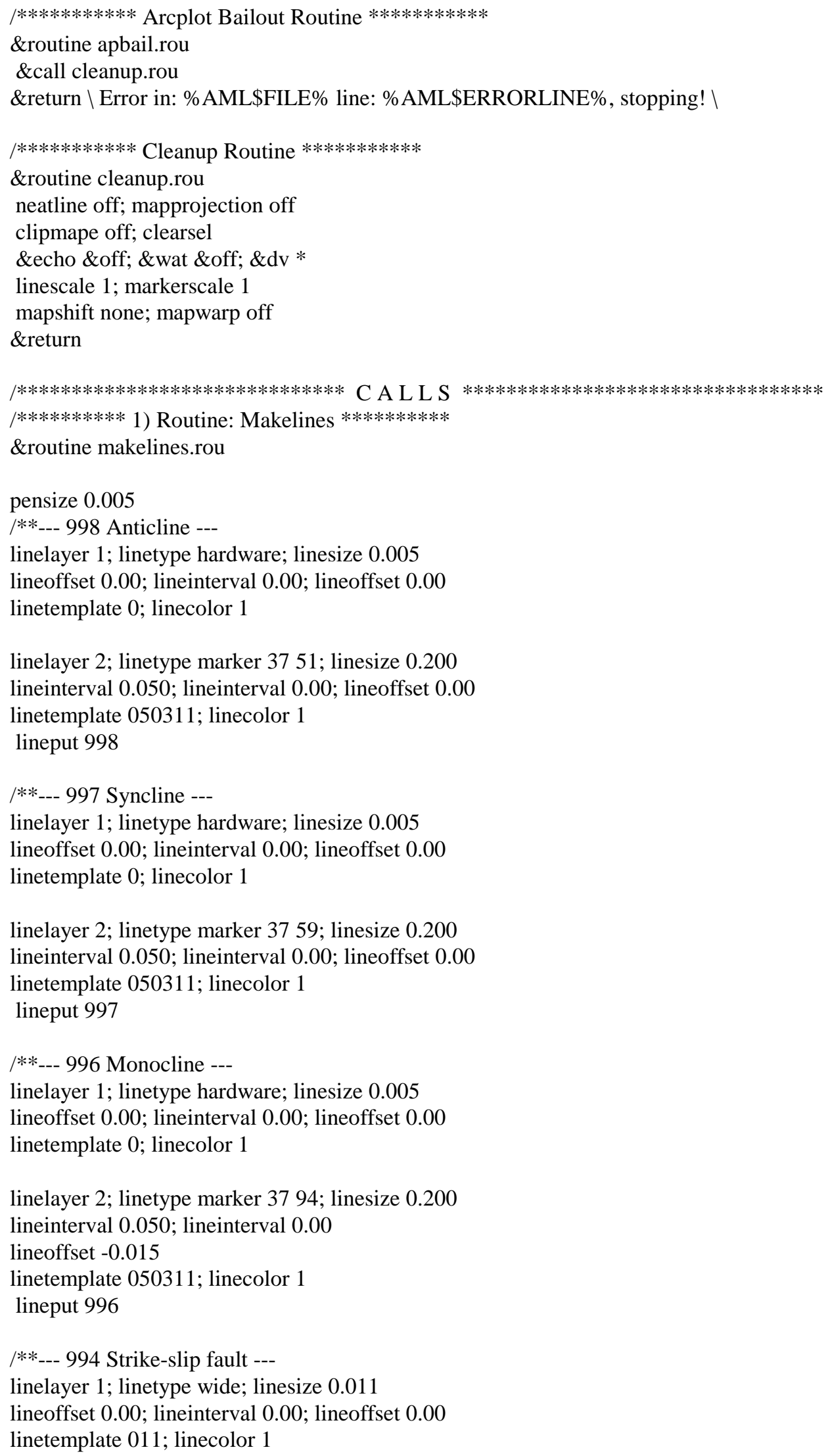


linelayer 2; linetype marker 37 70; linesize 0.20

lineoffset 0.00 ; lineinterval 0.300 ; lineoffset -0.001

linetemplate 011 ; linecolor 1

lineput 994

/**--- 993 Thrust fault ---

linelayer 1 ; linetype wide; linesize 0.015

lineoffset 0.00 ; lineinterval 0.00 ; lineoffset 0.00

linetemplate 011 ; linecolor 1

linelayer 2; linetype marker 17 84; linesize 0.060

lineoffset 0.00 ; lineinterval 0.300 ; lineoffset 0.05

linetemplate 011 ; linecolor 1

lineput 993

/**--- 992 Normal fault ---

linelayer 1 ; linetype wide; linesize 0.015

lineoffset 0.00 ; lineinterval 0.00 ; lineoffset 0.00

linetemplate 011 ; linecolor 1

linelayer 2; linetype marker 17 68; linesize 0.060

lineoffset 0.00 ; lineinterval 0.300 ; lineoffset 0.05

linetemplate 011 ; linecolor 1

linelayer 3; linetype marker 17 85; linesize 0.060

lineoffset 0.00 ; lineinterval 0.300 ; lineoffset -0.05

linetemplate 011 ; linecolor 1

lineput 992

linetype hardware; linesize 0.005

lineoffset 0.00 ; lineinterval 0.00 ; linetemplate 0

\&return

/**********2) Routine: Geology Features **********

\&routine geology.rou

/**--- Polys: azgeol ---

polygonshades azgeol unit azgeol.ru

/**--- Arcs: azgeol ---

resel azgeol arcs linecode lt 100

arclines azgeol linecode azgeol.con

clearsel

resel azgeol arcs linecode ge 100

arclines azgeol linecode azgeol.str

clearsel

/**--- Arcs: azfold ---

arclines azfold linecode azfold.str

/**--- Points: azptdec ---

markerscale 1

resel azptdec points ptcode $=120$

pointmarkers azptdec ptcode azptdec.lut

markerscale 0.7 
nsel azptdec points

pointmarkers azptdec ptcode azptdec.lut

markerscale 1

/**--- Points: azptfeat ---

markersym 522

resel azptfeat point ptcode $=405 / * *$ Cinder cones

points azptfeat noids

clearsel

markersym 524

resel azptfeat point ptcode $=410 / * *$ Diatremes

points azptfeat noids

clearsel

/**--- Smaller polygon text: azgeol ---

textsym 12 ; textsize 0.120 .12 ; textjust cc

textoffset 0,0 ; textalign center; textcolor 1

resel azgeol polys area gt 60000000 and area lt 500000000 and unit ne 'water'

labeltext azgeol unit

clearsel

/**--- Larger polygon text: azgeol ---

textsym 3 ; textsize 0.140 .14 ; textjust cc

textalign center; textoffset 0,0 ; textcolor 1

resel azgeol polys area gt 500000000 and unit ne 'water'

labeltext azgeol unit

clearsel

/**--- Arc text: azgeol ---

textsymb 1 ; textalign left; textjust 11

annotext azfold

\&return

/**********3) Routine: Top Collar Margin $* * * * * * * * * *$

\&routine topcollar.rou

textsym 14

textsize 0.30 .3

textoffset 0,0

/**--- Left ---

plot usgslogo.gra box 0.5 66.5 4.5 67.5/** USGS Logo

textjust ul

move 4.267 .3

text 'DEPARTMENT OF THE INTERIOR'

move 4.266 .8

text 'U.S. GEOLOGICAL SURVEY'

/**--- Center ---

textjust uc

move 2367.3

text 'PREPARED IN COOPERATION WITH THE'

move 2366.8

text 'UNIVERSITY OF ARIZONA' 


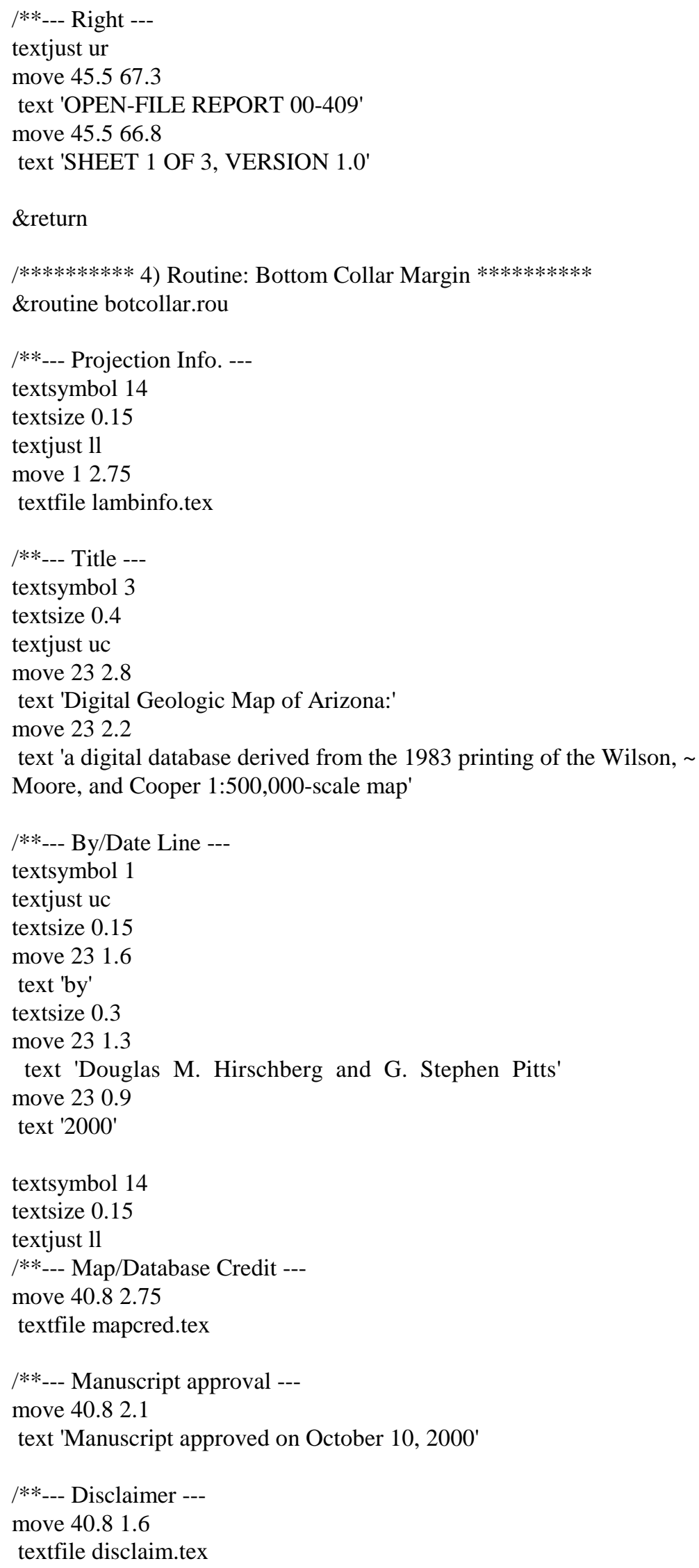




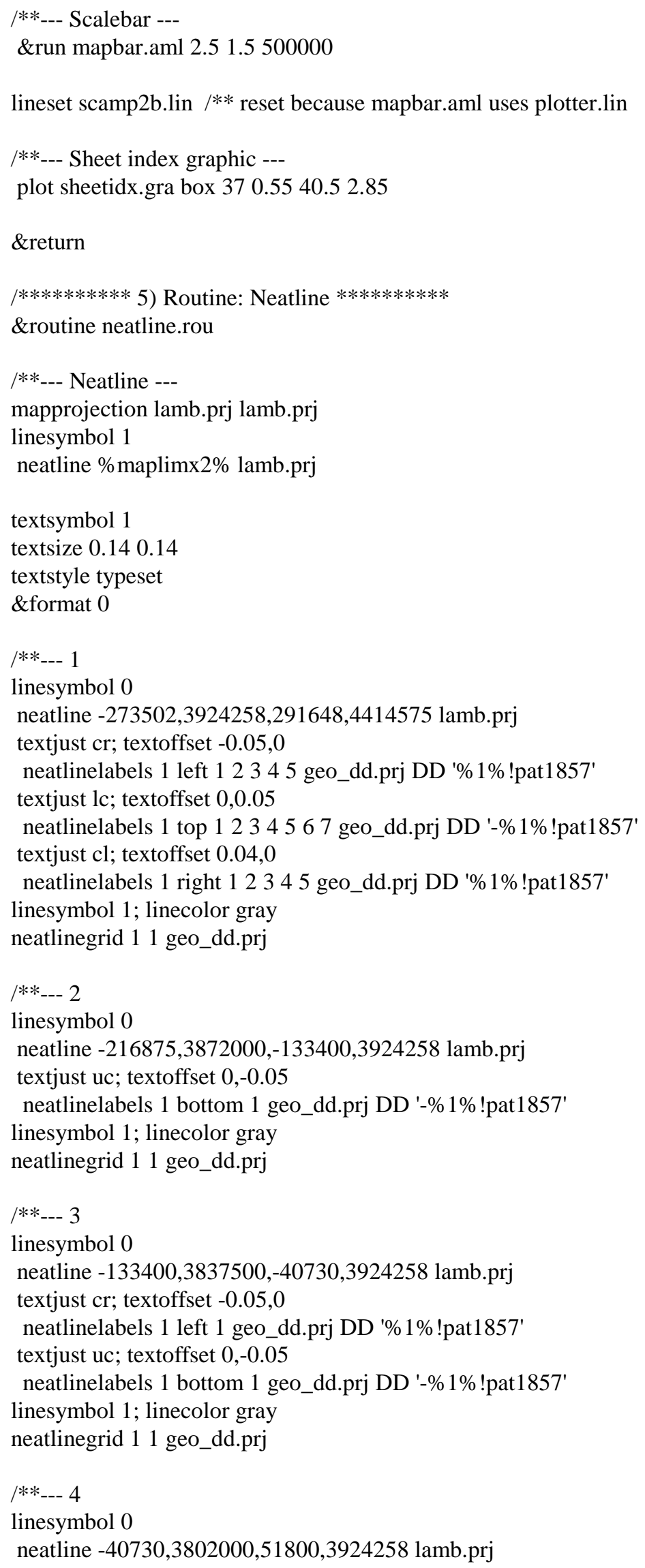


textjust uc; textoffset $0,-0.05$

neatlinelabels 1 bottom 1 geo_dd.prj DD '-\%1\%!pat1857'

linesymbol 1; linecolor gray

neatlinegrid 11 geo_dd.prj

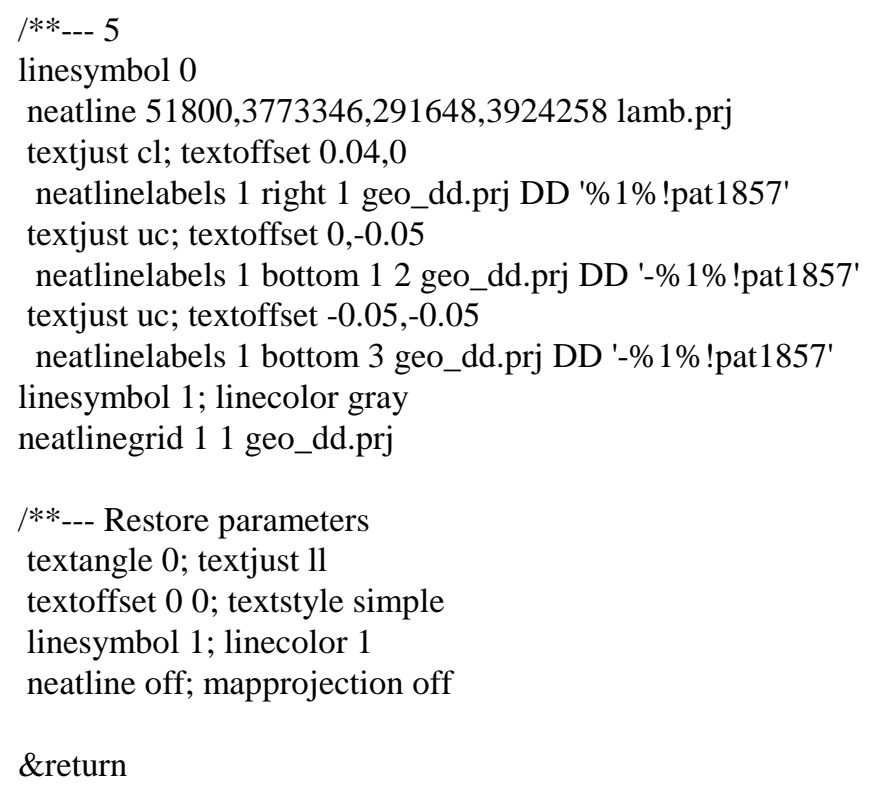




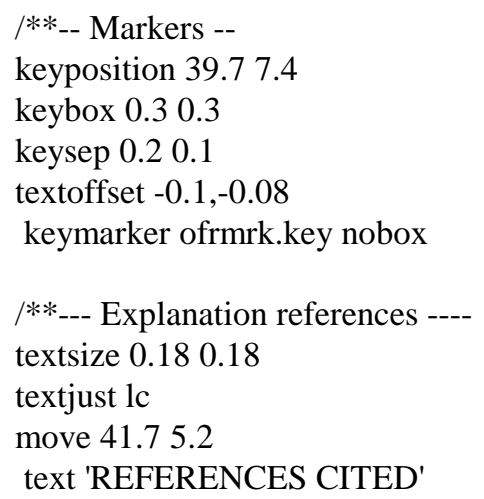


move 5.612 .9

text '[1983 printing]: U. S. Geological Survey Map G81036, scale 1:500,000 )'

/**--- Bibliography Explanation ---

textsymbol 14

textsize 0.140 .14

textjust 11

move 1.612 .6

text 'Sources cited have been locally modified or adjusted by the authors or by collaborating members of the staff of the United States Geological Survey.'

move 1.712 .4

text ' * Indicates published.'

move 1.712 .2

text ' + Indicates unpublished map made for use in compiling county map or maps published by the Arizona Bureau of Mines, 1957-60.'

/**--- Bibliography Text ---

textstyle typeset $\quad / * *$ Default is simple

textprecision automatic $/ * *$ Default is auto

textquality prop $\quad / * *$ Default is constant

textspacing 1.1,0 /** Default is 0,0

textalign left $\quad / * *$ Default is left

textoffset 0,0

textsymbol 14

textsize 0.140 .14

textjust 11

move 1.33 .4

textfile indxbib1.tex block

move 6.13 .82

textfile indxbib2.tex block

/**--- Restore Parameters ---

textsym 1 ; textsize 0.1

textspac 0,0 ; textstyle simple

textoffset 0,0

linecolor 1

\&return

/*** end of sheet1.aml program *** 


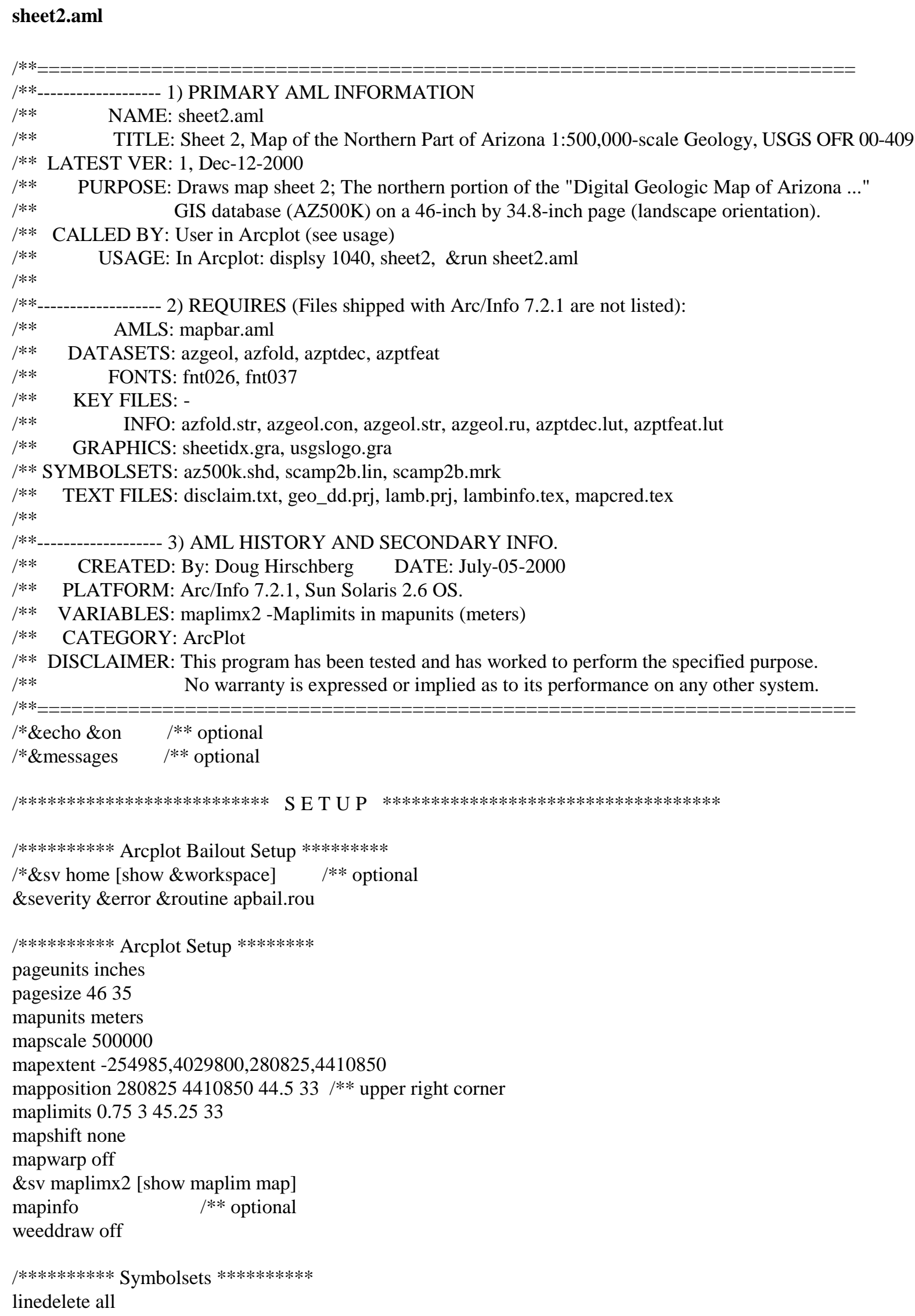




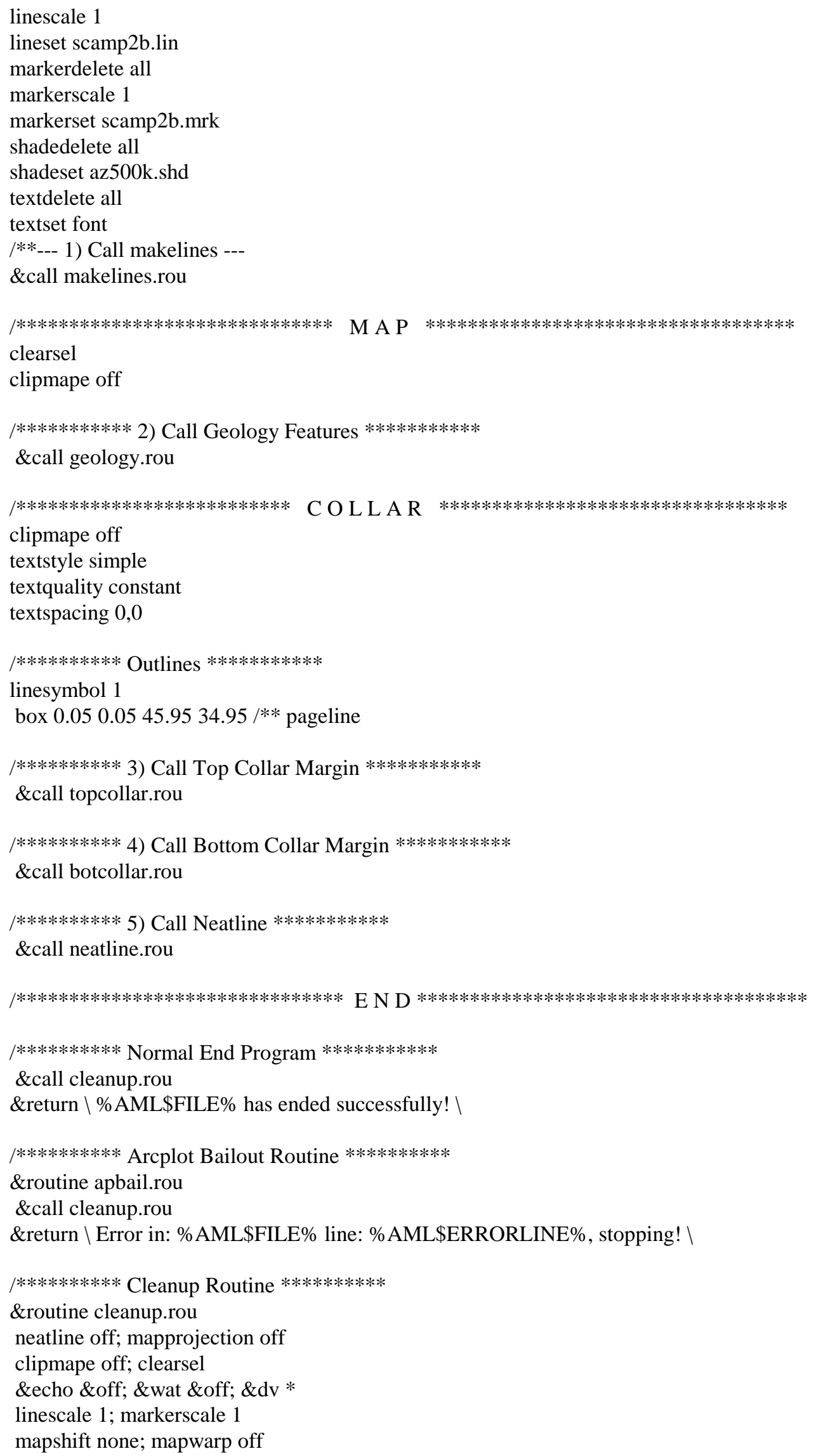


\&return

/********************************** $\mathrm{C} \mathrm{A} \mathrm{L} \mathrm{L} \mathrm{S} * * * * * * * * * * * * * * * * * * * * * * * * * * * * * * * * *$

/********** 1) Routines: Makelines $* * * * * * * * * *$

\&routine makelines.rou

pensize 0.005

/**--- 998 Anticline ---

linelayer 1; linetype hardware; linesize 0.005

lineoffset 0.00 ; lineinterval 0.00 ; lineoffset 0.00

linetemplate 0 ; linecolor 1

linelayer 2; linetype marker 3751 ; linesize 0.200

lineinterval 0.050 ; lineinterval 0.00 ; lineoffset 0.00

linetemplate 050311 ; linecolor 1

lineput 998

/**--- 997 Syncline ---

linelayer 1 ; linetype hardware; linesize 0.005

lineoffset 0.00 ; lineinterval 0.00 ; lineoffset 0.00

linetemplate 0 ; linecolor 1

linelayer 2; linetype marker 37 59; linesize 0.200

lineinterval 0.050; lineinterval 0.00; lineoffset 0.00

linetemplate 050311; linecolor 1

lineput 997

/**--- 996 Monocline ---

linelayer 1 ; linetype hardware; linesize 0.005

lineoffset 0.00 ; lineinterval 0.00 ; lineoffset 0.00

linetemplate 0 ; linecolor 1

linelayer 2; linetype marker 37 94; linesize 0.200

lineinterval 0.050 ; lineinterval 0.00

lineoffset -0.015

linetemplate 050311 ; linecolor 1

lineput 996

/**--- 994 Strike-slip Fault ---

linelayer 1; linetype wide; linesize 0.011

/*linelayer 1 ; linetype wide; linesize 0.015

lineoffset 0.00 ; lineinterval 0.00 ; lineoffset 0.00

linetemplate 011 ; linecolor 1

linelayer 2; linetype marker 37 70; linesize 0.20

lineoffset 0.00 ; lineinterval 0.300 ; lineoffset -0.001

linetemplate 011 ; linecolor 1

lineput 994

/**--- 993 Thrust Fault ---

linelayer 1 ; linetype wide; linesize 0.015

lineoffset 0.00 ; lineinterval 0.00 ; lineoffset 0.00

linetemplate 011 ; linecolor 1

linelayer 2; linetype marker 17 84; linesize 0.060 
lineoffset 0.00 ; lineinterval 0.300 ; lineoffset 0.05

linetemplate 011 ; linecolor 1

lineput 993

/**--- 992 Normal Fault ---

linelayer 1; linetype wide; linesize 0.015

lineoffset 0.00 ; lineinterval 0.00 ; lineoffset 0.00

linetemplate 011 ; linecolor 1

linelayer 2; linetype marker 17 68; linesize 0.060

lineoffset 0.00 ; lineinterval 0.300 ; lineoffset 0.05

linetemplate 011 ; linecolor 1

linelayer 3; linetype marker 1785 ; linesize 0.060

lineoffset 0.00 ; lineinterval 0.300 ; lineoffset -0.05

linetemplate 011 ; linecolor 1

lineput 992

linetype hardware; linesize 0.005

lineoffset 0.00 ; lineinterval 0.00

linetemplate 0

\&return

/**********2) Routine: Geology Features $* * * * * * * * * *$

\&routine geology.rou

/**--- Polys: azgeol ---

polygonshades azgeol unit azgeol.ru

/**--- Arcs: azgeol ---

resel azgeol arcs linecode lt 100

arclines azgeol linecode azgeol.con

clearsel

resel azgeol arcs linecode ge 100

arclines azgeol linecode azgeol.str

clearsel

/**--- Arcs: azfold ---

arclines azfold linecode azfold.str

/**--- Points: azptdec ---

markerscale 1

resel azptdec points ptcode $=120$

pointmarkers azptdec ptcode azptdec.lut

markerscale 0.7

nsel azptdec points

pointmarkers azptdec ptcode azptdec.lut

markerscale 1

/**--- Points: azptfeat ---

markersym 522

resel azptfeat point ptcode $=405 / * *$ Cinder cones

points azptfeat noids

clearsel

markersym 524 
resel azptfeat point ptcode $=410 / * *$ Diatremes

points azptfeat noids

clearsel

/**--- Smaller polygon text: azgeol ---

textsym 12 ; textsize 0.120 .12

textjust cc; textoffset 0,0

textalign center; textcolor 1

resel azgeol polys area gt 60000000 and area lt 500000000 and unit ne 'water'

labeltext azgeol unit

clearsel

/**--- Larger polygon text: azgeol ---

textsym 3 ; textsize 0.140 .14

textjust cc; textalign center

textoffset 0,0 ; textcolor 1

resel azgeol polys area gt 500000000 and unit ne 'water'

labeltext azgeol unit

clearsel

/**--- Arc text: azgeol ---

textsym 1

textalign left

textjust 11

annotext azfold

\&return

/**********3) Routine: Top Collar Margin $* * * * * * * * * *$

\&routine topcollar.rou

textsym 14

textsize 0.30 .3

textoffset 0,0

/**--- Left ---

plot usgslogo.gra box 0.533 .54 .534 .5 /** USGS Logo

textjust ul

move 4.234 .3

text 'DEPARTMENT OF THE INTERIOR'

move 4.233 .9

text 'U.S. GEOLOGICAL SURVEY'

/**--- Center ---

textjust uc

move 2334.3

text 'PREPARED IN COOPERATION WITH THE'

move 2333.9

text 'UNIVERSITY OF ARIZONA'

/**--- Right ---

textjust ur

move 45.534 .3

text 'OPEN-FILE REPORT 00-409'

move 45.533 .9

text [quote SHEET 2 OF 3, VERSION 1.0] 
\&return

/********** 4) Routine: Bottom Collar Margin **********

\&routine botcollar.rou

/**--- Projection Info. ---

textsymbol 14

textsize 0.15

textjust 11

move 0.752 .75

textfile lambinfo.tex

/**--- Title ---

textsymbol 3

textsize 0.4

textjust uc

move 232.75

text 'Digital Geologic Map of Arizona:'

move 232.1

text 'a digital database derived from the 1983 printing of the Wilson,

Moore, and Cooper 1:500,000-scale map'

/**--- By/Date Line ---

textsymbol 1

textsize 0.15

textjust uc

move 231.45

text 'by'

textsize 0.3

textjust uc

move 231.2

text 'Douglas M. Hirschberg and G. Stephen Pitts'

move 230.8

text '2000'

textsymbol 14

textsize 0.15

textjust 11

/**--- Map/Database Credit ---

move 40.92 .75

textfile mapcred.tex

/**--- Manuscript Approval ---

move 40.92 .1

text 'Manuscript approved on October 10, 2000'

/**--- Disclaimer ---

move 40.91 .6

textfile disclaim.tex

/**--- Scalebar ---

\&run mapbar.aml 21.25500000

lineset scamp2b.lin $/ * *$ reset because mapbar.aml uses plotter.lin 


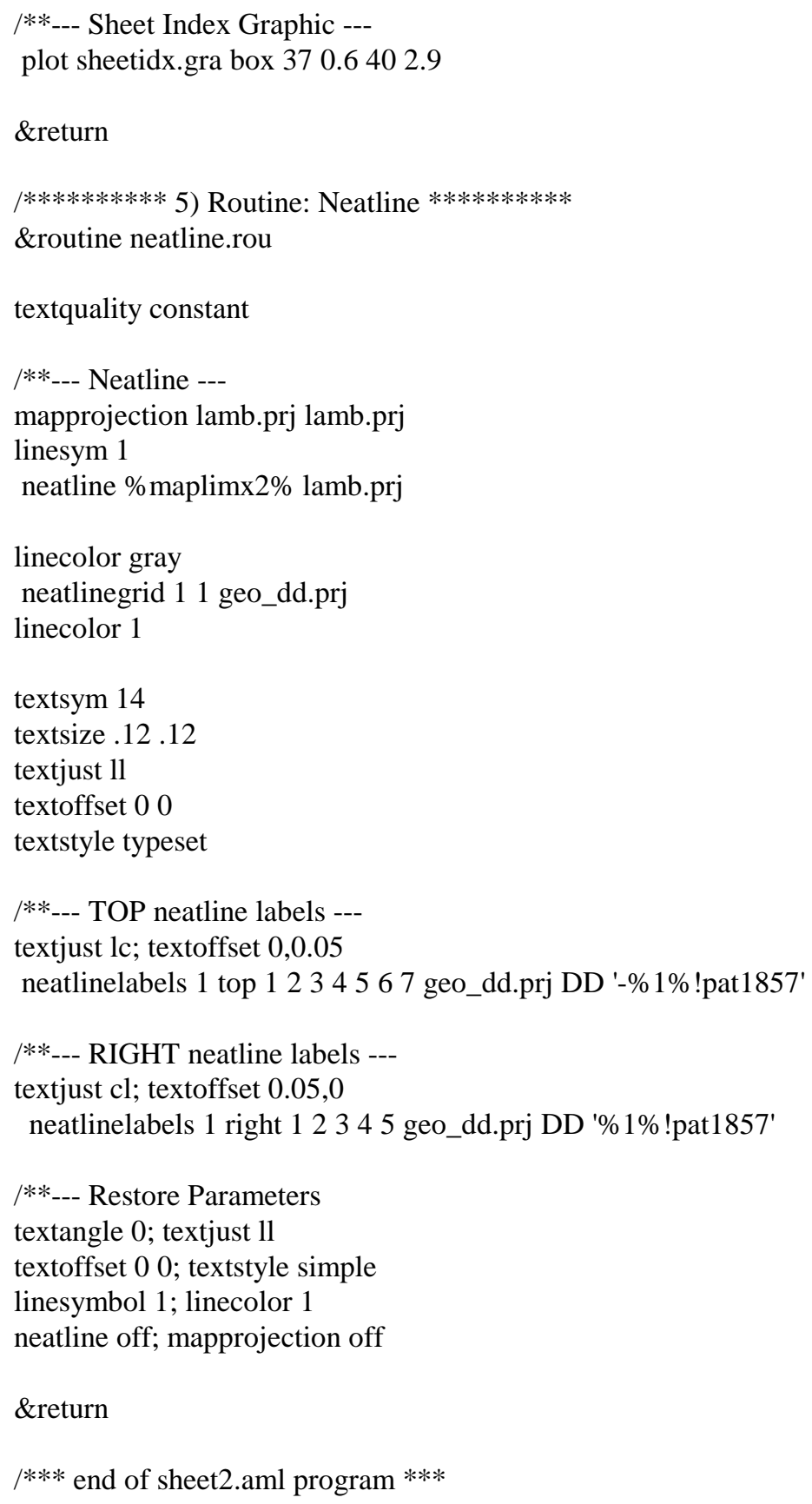




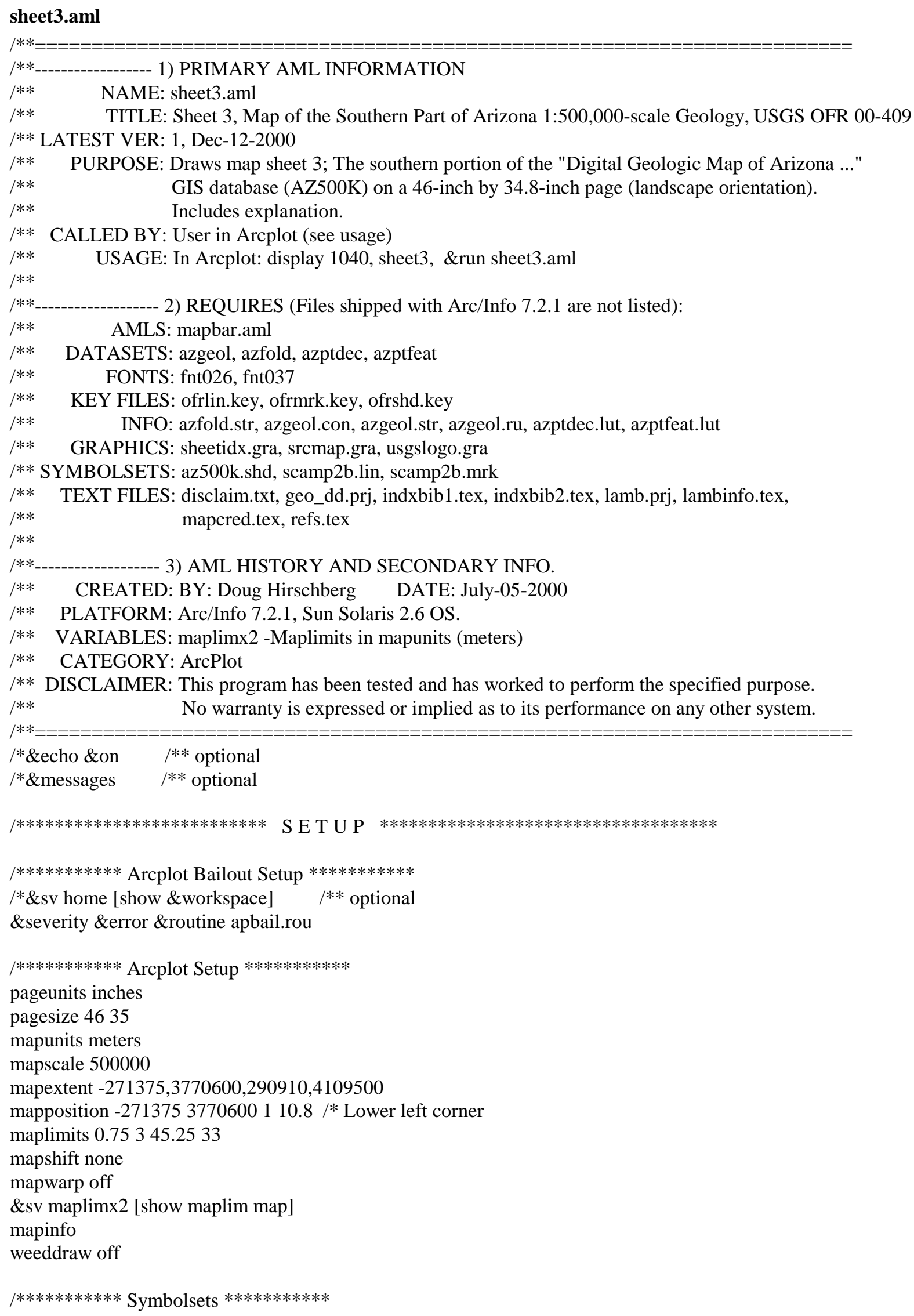




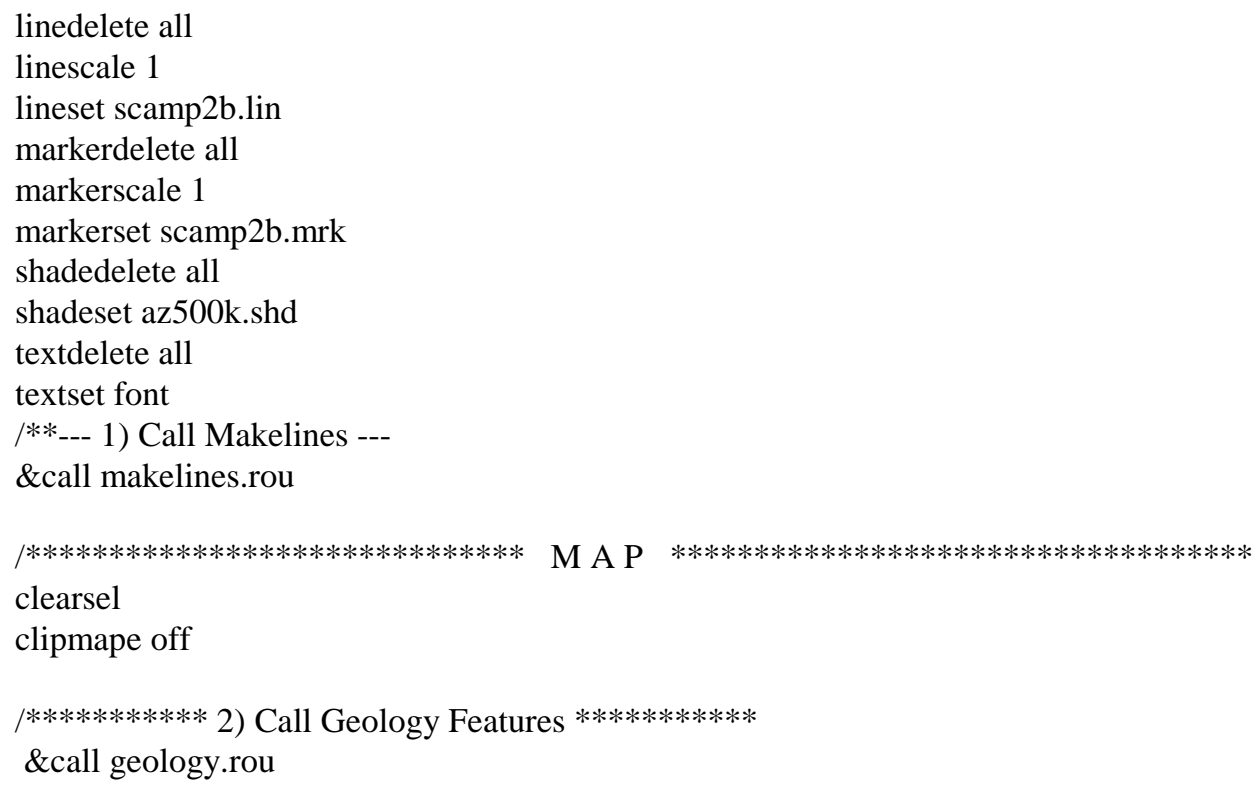




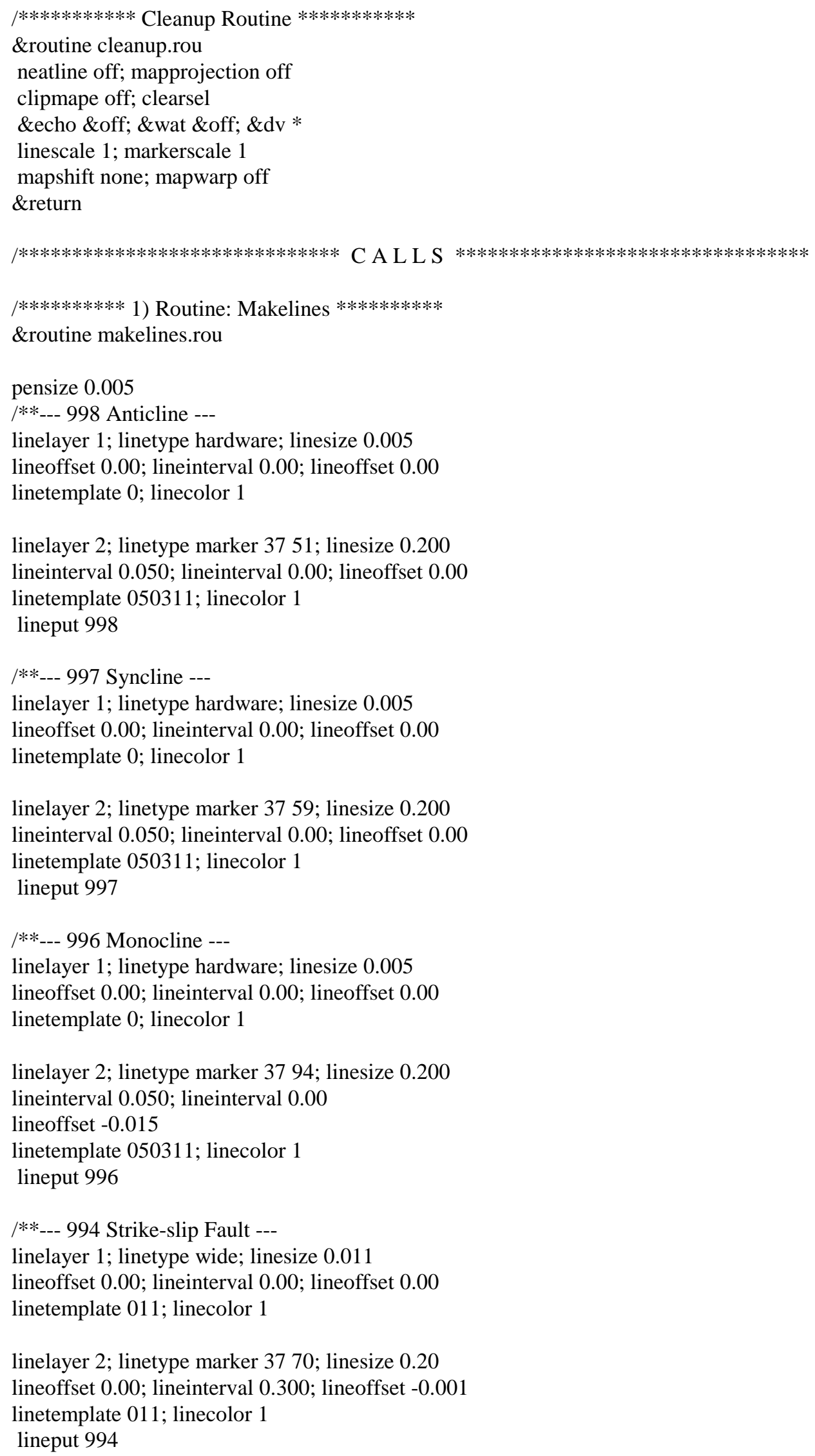




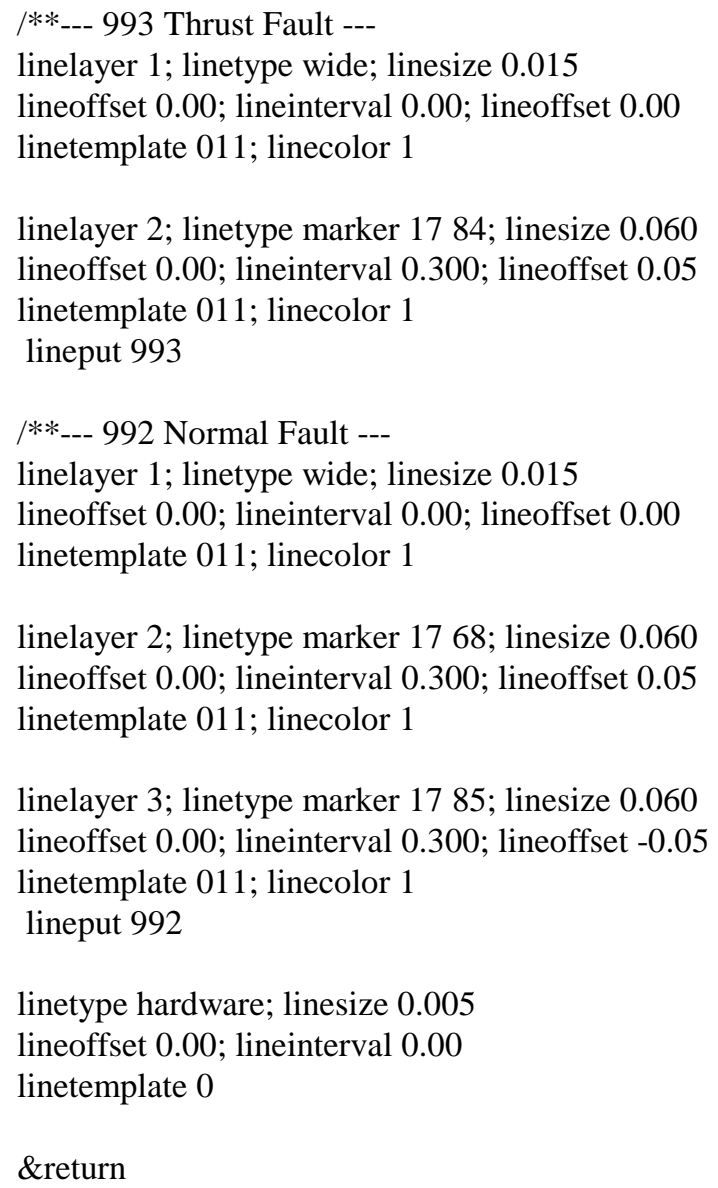




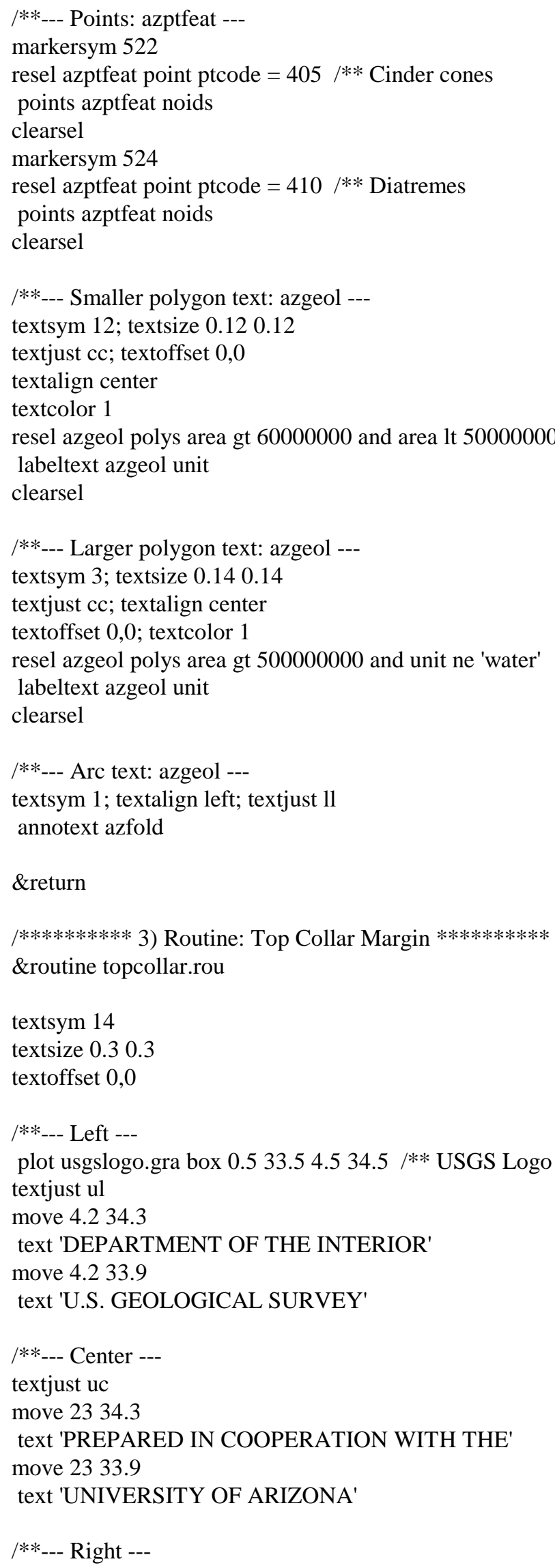


textjust ur

move 45.534 .3

text 'OPEN-FILE REPORT 00-409'

move 45.533 .9

text [quote SHEET 3 OF 3, VERSION 1.0]

\&return

/**********4 4) Routine: Bottom Collar Margin **********

\&routine botcollar.rou

/**--- Projection Info. ---

textsymbol 14

textsize 0.15

textjust 11

move 0.752 .75

textfile lambinfo.tex

/**--- Title ---

textsymbol 3 ; textsize 0.4

textjust uc

move 232.75

text 'Digital Geologic Map of Arizona:'

move 232.1

text 'a digital database derived from the 1983 printing of the Wilson, Moore, and Cooper 1:500,000-scale map'

/**--- By/Date Line ---

textsymbol 1 ; textsize 0.15

textjust uc

move 231.45

text 'by'

textsize 0.3 ; textjust uc

move 231.2

text 'Douglas M. Hirschberg and G. Stephen Pitts'

move 230.8

text '2000'

textsymbol 14 ; textsize 0.15

textjust 11

/**--- Map/Database Credit ---

move 40.92 .75

textfile mapcred.tex

/**--- Manuscript approval ---

move 40.92 .1

text 'Manuscript approved on October 10, 2000'

/**--- Disclaimer ---

move 40.91 .6

textfile disclaim.tex

/**--- Scalebar ---

\&run mapbar.aml 21.25500000

lineset scamp2b.lin $/ * *$ reset because mapbar.aml uses plotter.lin 


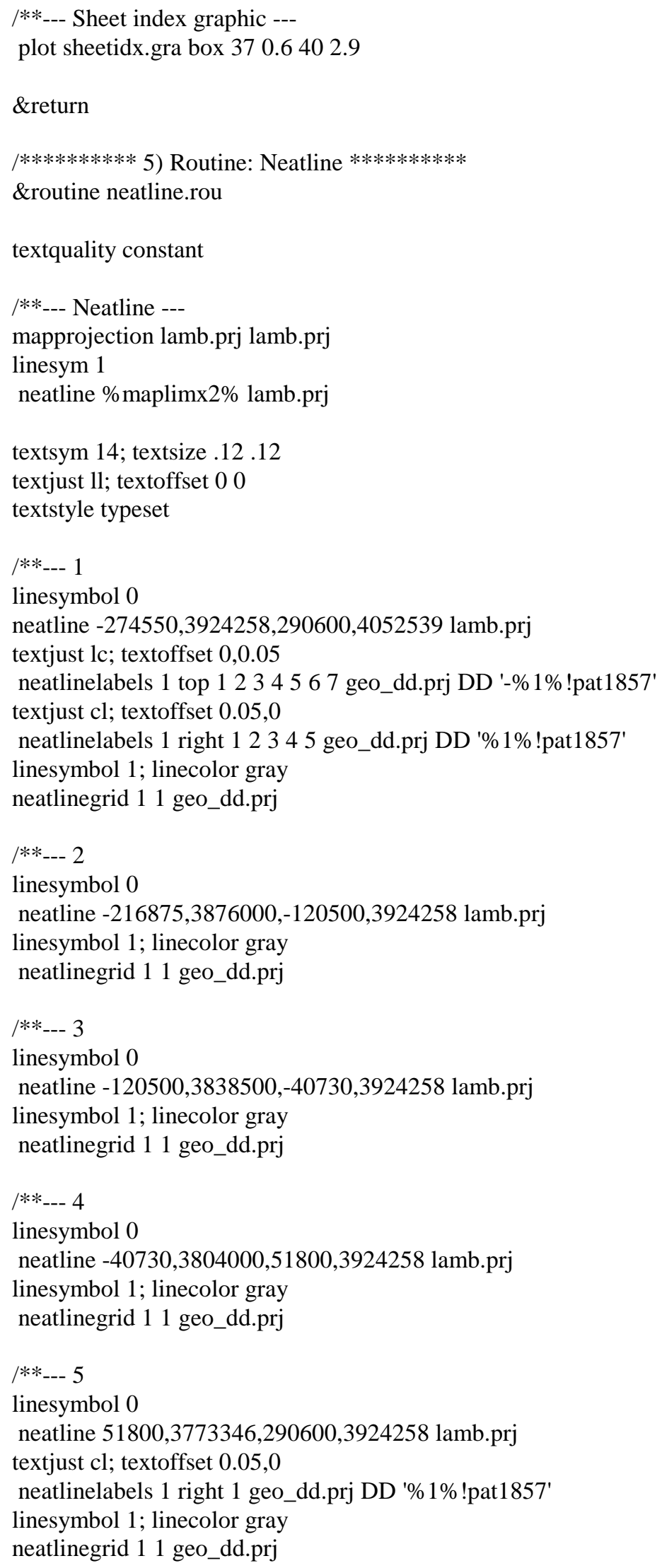




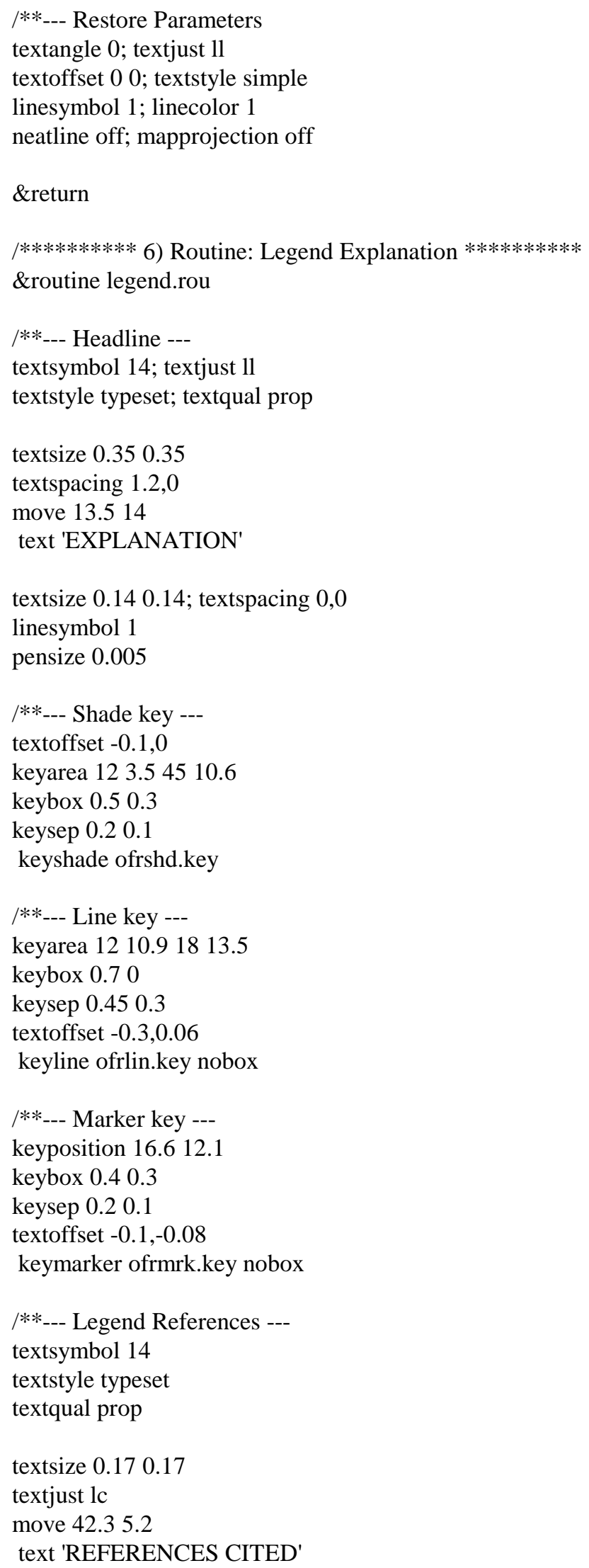


textspac $1.1,1.1$; textalign left

textoffset 0,0

move 40.23 .5

textfile refs.tex block

\&return

/********** 7) Routine: Sources Index Map \& Bibliography **********

\&routine index.rou

textstyle typeset; textprecision automatic

textqual prop; textspacing 1.1,0

textalign left; textoffset 0,0

/**--- Sources Map Graphic ---

plot srcmap.gra box 3.2 13.4 8.8 18.9

/**--- Sources "Geologic Map of Arizona" Title Line ---

textsymbol 16 ; textsize 0.240 .24

textjust lc

move 613

text 'Data sources for the "Geologic Map of Arizona"'

textsize 0.180 .18

move 612.7

text '( Wilson, E. D., Moore, R. T., and Cooper, J. R., 1969, Geologic Map of Arizona'

move 612.45

text '[1983 printing]: U. S. Geological Survey Map G81036, scale 1:500,000 )'

/**--- Bibliography explanation ----

textsymbol 14

textsize 0.120 .12

textjust 11

move 212.1

text 'Sources cited have been locally modified or adjusted by the authors or by collaborating members of the staff of the United States Geological Survey.'

move 211.9

text ' * Indicates published.'

move 211.7

text ' + Indicates unpublished map made for use in compiling county map or maps published by the Arizona Bureau of Mines, 1957-60.'

/**--- Bibliography Text ---

textsymbol 14

textsize 0.140 .14

textjust 11

move 1.33 .15

textfile indxbib1.tex block

move 6.33 .6

textfile indxbib2.tex block

\&return

/*** end of sheet3.aml program *** 